\title{
Single-particle characterization of the high-Arctic summertime aerosol
}

\author{
B. Sierau ${ }^{1}$, R. Y.-W. Chang ${ }^{2, *}$, C. Leck ${ }^{3}$, J. Paatero ${ }^{4}$, and U. Lohmann ${ }^{1}$ \\ ${ }^{1}$ Institute for Atmospheric and Climate Science, ETH Zurich, Zurich, Switzerland \\ ${ }^{2}$ Department of Chemistry, University of Toronto, Toronto, Canada \\ ${ }^{3}$ Department of Meteorology, Stockholm University, Stockholm, Sweden \\ ${ }^{4}$ Finnish Meteorological Institute, Helsinki, Finland \\ *now at: Department of Earth and Planetary Sciences, Harvard University, Cambridge, USA
}

Correspondence to: B. Sierau (berko.sierau@env.ethz.ch)

Received: 15 December 2013 - Published in Atmos. Chem. Phys. Discuss.: 9 January 2014

Revised: 23 May 2014 - Accepted: 9 June 2014 - Published: 18 July 2014

\begin{abstract}
Single-particle mass-spectrometric measurements were carried out in the high Arctic north of $80^{\circ}$ during summer 2008. The campaign took place onboard the icebreaker Oden and was part of the Arctic Summer Cloud Ocean Study (ASCOS). The instrument deployed was an aerosol time-offlight mass spectrometer (ATOFMS) that provides information on the chemical composition of individual particles and their mixing state in real time. Aerosols were sampled in the marine boundary layer at stations in the open ocean, in the marginal ice zone, and in the pack ice region. The largest fraction of particles detected for subsequent analysis in the size range of the ATOFMS between approximately 200 and $3000 \mathrm{~nm}$ in diameter showed mass-spectrometric patterns, indicating an internal mixing state and a biomass burning and/or biofuel source. The majority of these particles were connected to an air mass layer of elevated particle concentration mixed into the surface mixed layer from the upper part of the marine boundary layer. The second largest fraction was represented by sea salt particles. The chemical analysis of the over-ice sea salt aerosol revealed tracer compounds that reflect chemical aging of the particles during their long-range advection from the marginal ice zone, or open waters south thereof prior to detection at the ship. From our findings we conclude that long-range transport of particles is one source of aerosols in the high Arctic. To assess the importance of long-range particle sources for aerosol-cloud interactions over the inner Arctic in comparison to local and regional biogenic primary aerosol sources, the chemical composition of the detected particles was analyzed for indicators of ma-
\end{abstract}

rine biological origin. Only a minor fraction showed chemical signatures of potentially ocean-derived primary particles of that kind. However, a chemical bias in the ATOFMS's detection capabilities observed during ASCOS might suggest the presence of a particle type of unknown composition and source. In general, the study suffered from low counting statistics due to the overall small number of particles found in this pristine environment, the small sizes of the prevailing aerosol below the detection limit of the ATOFMS, and its low hit rate. To our knowledge, this study reports on the first in situ single-particle mass-spectrometric measurements in the marine boundary layer of the high-Arctic pack ice region.

\section{Introduction}

The Arctic pack ice region is undergoing dramatic changes due to global warming (e.g., IPCC, 2007; Jeffries and Richter-Menge, 2012). These changes affect not only the extent and thickness of the Arctic sea ice (Lindsay et al., 2009) but also the influence of physical and chemical processes of the aerosols on the regional climate (e.g., Curry et al., 2000; Prenni et al., 2007). Herein, radiative effects of aerosol particles and aerosol-cloud interactions play a substantial role: aerosols interact with solar radiation directly by scattering or absorbing sunlight. Also, certain aerosols have the ability to serve as cloud condensation nuclei $(\mathrm{CCN})$ and/or ice nuclei (IN); in other words, they activate to water droplets and/or ice crystals to form clouds. This process determines 
the microphysical structure and lifetime of clouds with possible consequences for the planetary albedo and the surface energy budget and thus for the melting and freezing of the perennial sea ice (Intrieri et al., 2002; Sedlar et al., 2011; Tjernström et al., 2005). Both the radiative effects of aerosols and their role in cloud forming processes depend on the number, size, chemical properties, and mixing state of the particles. The latter parameters are determined by the source of the particles and atmospheric gas-phase and aerosol dynamical processes acting on the particles during their atmospheric lifetime. As a consequence, a better understanding of Arctic climate change involves, among other things, the characterization of the Arctic aerosol. This includes measuring the particles' physicochemical properties in situ and elucidating their atmospheric history, i.e., assigning particle sources and understanding the processes shaping the aerosols during their residence time in the atmosphere.

Information on the chemical composition and sources of the aerosol in subarctic regions is plentiful; information on the chemical composition and sources of the high-Arctic $\left(>80^{\circ} \mathrm{N}\right)$ aerosol over the pack ice area is, however, scarce. In the past, attention has mainly been directed towards the investigation of aerosols that play a role in the phenomenon known as "Arctic haze": during winter and early spring, high concentrations of sulfate and black carbon (BC) containing particles from continental, anthropogenic sources are transported into the central Arctic, leading to a substantial decrease in visibility and enhanced air pollution (Heintzenberg, 1980). During these periods, air masses from continental source regions located at lower latitudes influence the central Arctic, which mainly explains the high atmospheric burden of anthropogenic aerosols in this remote area (Quinn et al., 2007). During summer, the central Arctic region, however, is largely isolated from long-range-transported air from lower latitudes (Stohl, 2006; Law and Stohl, 2007; Heintzenberg and Leck, 2004), causing local aerosol sources to become important.

A large portion of our knowledge of the in situ measured properties of the summertime high-Arctic aerosol north of $80^{\circ}$ stems from three research expeditions all carried out on the icebreaker Oden in 1991, 1996, and 2001 (Leck et al., 1996, 2001, 2004; Tjernström et al., 2004) as well as from the most recent experiment in 2008: the Arctic Summer Cloud Ocean Study (ASCOS; Tjernström et al., 2013), the latter being the focus of this publication. The overriding aim of these expeditions was to improve our understanding of lowlevel stratiform cloud formation and evolution in summer over the high-Arctic pack ice area north of $80^{\circ}$ in order to clarify processes between the surface, cloud layers, and free troposphere. In these studies, particle nucleation (e.g., Covert et al., 1996; Wiedensohler et al., 1996; Leck and Bigg, 1999; Karl et al., 2013), large-scale advection of aerosols from lower latitudes into the inner part of the pack ice area (e.g., Bigg, 1996; Heintzenberg and Leck, 2004; Shupe et al., 2013), and particles ejected from the open leads due to bub- ble bursting (e.g., Leck and Bigg, 2005a) have been identified to contribute to the atmospheric burden of particles during summertime. The high-Arctic open leads can be described as ever-changing open water channels comprising 10-30\% of the ice pack ice area, ranging from a few meters up to a few kilometers in width. From ASCOS, measurements of open lead particle emissions and bubble size spectra within the near-surface waters of open leads were analyzed by Held et al. (2011) and Norris et al. (2011), respectively, and further discussed in Tjernström et al. (2013). Nevertheless, the source strengths of the primary biogenic particles, their relative abundances, and their physical and chemical properties are still unknown. The question of whether the source of aerosol particles for the omnipresent summer central Arctic low-level clouds (Curry and Ebert, 1992; Tjernström et al., 2005; Shupe et al., 2005, 2011) is local or whether aerosols are imported by long-range transport from the free troposphere or by advection in the marine boundary layer from the marginal ice zone (MIZ), or south thereof, is critical for understanding Arctic climate and climate change processes. Since CCN and IN number concentrations in the central Arctic are very low, small changes can substantially alter the clouds and their impacts on the surface - that is, melting or freezing of the ice (Intrieri et al., 2002; Tjernström, 2005; Mauritsen et al., 2011).

In situ measurements of the bulk chemical composition of the non-refractory, submicron high-Arctic aerosol during ASCOS was carried out by Chang et al. (2011) using an aerosol mass spectrometer (AMS). The particles collected in the marine boundary layer were mainly composed of organics and sulfate. A source-apportionment study based on the AMS data revealed the influence of predominantly marine biogenic and continental sources. A type of purely organic aerosol was detected whose source could not be unambiguously identified. The authors Chang et al. (2011) suggest that these particles originate from primary marine sources or biomass burning and oxidized continental sources. The observed high degree of oxygenation of the organic components was interpreted as an indication of the presence of atmospherically processed aerosol. Directly emitted, primary marine organic particles of similar oxidation state as proposed by Leck and Bigg (2005b), however, could also have explained this observation. The primary organic particles described in Leck and Bigg (2005b) refer to marine polymer gels or marine gels (Verdugo, 2012) produced by biological secretions of phytoplankton and sea-ice algae and were hypothesized to originate from the sea surface microlayer of the open leads (e.g., Bigg et al., 2004; Leck and Bigg, 2005b, 2010; Bigg and Leck, 2008). Orellana et al. (2011) verified the presence of airborne marine gels in aerosols and fog and cloud water, demonstrating their origin as being injected into the atmosphere by bubble bursting. The gels are water insoluble and show thermally stable (Decho, 1990), i.e., refractory, properties which cannot be resolved by the AMS. Aerosol mass spectrometers employing a laser desorption ionization 
technique such as the one used in this study, the so-called aerosol time-of-flight mass spectrometer (ATOFMS; Gard et al., 1997), are capable of detecting refractory material; utilizing an ATOFMS over the eastern Pacific Ocean, Indian Ocean, and the western Pacific Ocean, Gaston et al. (2011) detected a unique ocean-derived particle type in the marine atmosphere whose mass-spectrometric pattern and correlation with sea salt aerosol showed a connection to the marine gels as described in Leck and Bigg (2005b).

Other monitoring or campaign data on the chemical composition of the Arctic aerosol were collected at lower latitudes, different seasons, or in the free troposphere and thus are not directly comparable to the marine boundary layer measurements performed on the icebreaker Oden during the summertime expeditions. Kuhn et al. (2010) report on AMS measurements performed during a summer study in 2006 at the Polar Environment Atmospheric Research Laboratory (PEARL) located in the Canadian High Arctic $\left(80^{\circ} \mathrm{N}\right)$. Long-term measurement of the Arctic's aerosol chemical composition from several research sites $\left(63\right.$ to $\left.82^{\circ} \mathrm{N}\right)$ are summarized in Quinn et al. (2007). These studies draw a conclusive picture of the seasonality of sulfate and biomass burning aerosol in the Arctic which is consistent with results from the ARCPAC (Aerosol, Radiation, and Cloud Processes affecting Arctic Climate) project of spring 2008 (Brock et al., 2011). Their findings concerning the influence of continental sources on the Arctic aerosol will be discussed in context with our findings from ASCOS. The listed studies, however, refer to data mainly collected south of $80^{\circ} \mathrm{N}$ and do not include the characterization of the aerosol sampled in the marine boundary layer over the pack ice area.

Recapitulating the measurements of the chemical composition of high-Arctic aerosol, the need for more in situ data collected at locations north of $80^{\circ}$ is obvious. Herein, we report on the first in situ single-particle mass-spectrometric measurements in the marine boundary layer of the central Arctic pack ice region, performed during the ASCOS experiment in summer 2008 on the icebreaker Oden. The main objective of the campaign was to investigate the formation of low-level stratiform clouds and its connection to meteorology and aerosol-cloud interactions (Tjernström et al., 2012, 2013). The focus was on the biologically active period of the Arctic summer in order to improve our understanding of aerosol sources from the ocean-surface microlayer and the potential of those particles to act as CCN and/or IN. Our online chemical mapping of individual single particles utilized an ATOFMS (TSI Inc., St. Paul, USA). The analysis of aerosol particles on a single-particle basis allows us to elucidate specific aerosol types and to identify aerosol sources based on their mixing state and chemical constituents. In contrast to the AMS, the ATOFMS analyzes refractory material that allows, for example, the speciation of elemental carbon, mineral material, and alkaline metals, and to identify their origins: for example, particles from fossil fuel combustion, dust, or of biological origin (e.g., Pratt and Prather,
2010; Creamean et al., 2013), such as primary marine particles (Gaston et al., 2011; Prather et al., 2013). Herein, the chemical composition of the single particles will be analyzed and compared to the results from the bulk analysis presented in Chang et al. (2011) and other studies as listed above.

\section{Methods}

\subsection{Area and time of operation}

The ASCOS field experiment (Tjernström et al., 2013) took place in the high-Arctic region from 2 August to 9 September 2008. The data discussed in this study were collected onboard the Swedish icebreaker Oden. The research cruise started and ended at Longyearbyen, Svalbard. Data collected during three sampling periods at different locations are presented: firstly, data from an open water station (OW) at 0:00 to $12: 00 \mathrm{UTC}$ on 3 August $2008\left(78.2^{\circ} \mathrm{N}, 7.5^{\circ} \mathrm{E}\right)$; secondly, from a marginal ice zone station (MIZ) on 4 August 2008 12:00 to 5 August $12: 00 \mathrm{UTC}\left(79.9^{\circ} \mathrm{N}, 6.1^{\circ} \mathrm{E}\right)$; and thirdly, measurements taken at an ice floe station (IF) in the pack ice $\left(>87^{\circ} \mathrm{N}\right)$ when the icebreaker was moored to an ice floe and drifted passively. The latter period from 12 August to 2 September represents the longest sampling period, 22 days in total. A map of the route including the ice drift period is shown in Fig. 1.

\subsection{Aerosol sampling}

The largest part of the aerosol instrumentation was in a laboratory container located on the deck of the Oden. The sample air was drawn in from about $25 \mathrm{~m}$ above sea level into the laboratory container via pipes of a two-masted gas- and particlesampling manifold that extended at an angle of $45^{\circ}$ to about $3 \mathrm{~m}$ above the roof of the container. Each mast was equipped with a horizontally oriented commercial $\mathrm{PM}_{1}$ and $\mathrm{PM}_{10}$ inlet, but the $\mathrm{PM}_{1}$ inlet mast also served as fixture for the gas-phase sampling lines. The ATOFMS and most of the other aerosol instrumentation were connected to the $\mathrm{PM}_{10}$ inlet through the main pipe, which had an inner diameter of $9 \mathrm{~cm}$ and was pumped with a total flow of approximately $1140 \mathrm{~L} \mathrm{~min}^{-1}$. Inside the container, aerosol samples were collected isokinetically from the main flow using forward-pointing inlets located in the center of the main pipe. The ATOFMS was connected to the main pipe via $3 / 8$ in. steel tubing $(230 \mathrm{~cm}$ in length) and $6 \mathrm{~mm}$ conductive tubing $(55 \mathrm{~cm}$ in length) that was branched from the steel tubing. A Reynolds number of $\sim 1700$ in the distribution line ensured laminar flow conditions and short residence times of the particles before being analyzed. The ATOFMS sample flow was $0.1 \mathrm{~L} \mathrm{~min}^{-1}$. The $\mathrm{RH}$ of the sample flow was assumed to be less than $30 \%$ based on the residence time of the air inside the flow system and the temperature difference between ambient and laboratory temperature. During one of the past expeditions the $\mathrm{RH}$ 


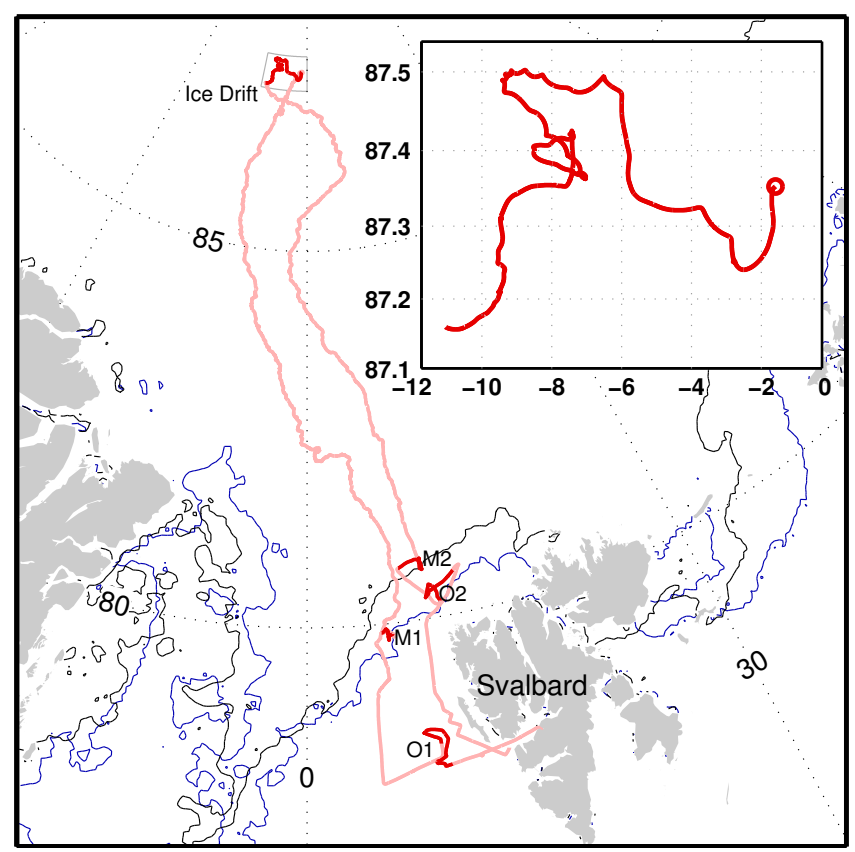

Figure 1. Map of the ASCOS route. O1 represents the open water station (named OW station in this paper), M1 the marginal ice zone station (named MIZ station in this paper), and the "ice drift" (named ice floe (IF) station in this paper). The blue and black lines describe the extent of the ice at the time of entry and exit. The inset shows details of the ice drift period. For instrument safety reasons, the ATOFMS was not measuring during the traverse between the MIZ and IF station, nor was it during the return cruise.

was measured to be $20 \%$ in a similar setting to that of ASCOS.

The construction and location of the sampling manifold was designed to optimize the distance from the sea and from the ship's superstructure. Direct contamination from the ship was excluded by using a pollution control mechanism based on a threshold signal from an ultrafine particle counter. The inlet system was already in use onboard the Oden during the first of the icebreaker campaigns in 1991. Provided that the wind was within $\pm \sim 70^{\circ}$ of the direction of the bow and stronger than $2 \mathrm{~m} \mathrm{~s}^{-1}$, no pollution reached the sample inlets (Leck and Persson, 1996). To maximize the sampling time, it was necessary to face the ship into the wind. For the ice drift this necessitated finding, or making, a "harbor" in the ice where the ship could be moored in several main orientations and turned as the wind direction changed. More details of the setup for the sampling of aerosol particles are given in Leck et al. (2001) and Tjernström et al. (2013).

\subsection{Aerosol time-of-flight mass spectrometry}

The chemical composition of the individual particles was obtained in real time using an ATOFMS (model 3800; TSI Inc., St. Paul, MA, USA); a detailed description of this can be found elsewhere (Gard et al., 1997, 1998). Particles are drawn into the instrument through an aerodynamic lens working in the size range of between approximately 200 and $3000 \mathrm{~nm}$ in diameter. Downstream of the lens the particles enter a differentially pumped vacuum stage where they are accelerated to their terminal velocity. They pass two continuous wave laser beams $(532 \mathrm{~nm})$ with a known fixed distance and are detected by their scattering pulses (in the following termed "sized" or "detected" particles). The vacuum aerodynamic diameter of each individual particle can then be determined from the transit time between the two lasers after calibrating the measured speed and the aerodynamic diameter using polystyrene latex spheres of known size and density. In the mass spectrometer source region, the sized particles are irradiated directly by a laser pulse of a $266 \mathrm{~nm} \mathrm{Nd:YAG} \mathrm{laser}$ with an energy of about $1 \mathrm{~mJ}$ to desorb sample-related ions. Positive and negative ions are then simultaneously detected in unit mass resolution using a dual-reflectron time-of-flight mass spectrometer (in the following termed "hit" or "chemically analyzed" particles). The mass calibration of the timeof-flight signal is obtained by analyzing particles of known composition.

Zero-particle measurements were performed regularly during the cruise by installing a filter upstream of the ATOFMS to check for false particle counts or instrumental noise. No false particle counts were detected during these "blank" measurements.

During the traverse through the pack ice, no data were collected, as the mass spectrometer was turned off for safety reasons. Also, the ATOFMS was not operational most of the time from 15 to 18 August (to be more exact, day of year (DoY) 228.125 to 231.125 as used later on) and from 18 to 19 August (DoY 231.292 to 232.250) for instrument maintenance.

\subsection{ATOFMS data processing and analysis}

Basic mass spectra analysis, e.g., mass and size calibrations applied to the data sets, was done using the TSI firmware MS-Analyze. For cluster analysis, the single-particle mass spectra generated by the ATOFMS were imported into the software system ENvironmental CHemistry through InteLligent Atmospheric Data Analysis (ENCHILADA; Gross, 2011). ENCHILADA enables the analysis of mass spectra by providing a variety of data-mining and visualization tools. In ENCHILADA, the aerosol particle data were clustered based on the mass spectral peaks and intensities through an ART$2 \mathrm{a}$ algorithm. The produced centers of the individual clusters represent an average of all the particles in that cluster, and each cluster represents a grouping of particles with mass spectral similarities. Thus, this particle classification method is indicative of particle chemistry and sources. Peak identification within the analysis corresponds to the most probable ions for a given $\mathrm{m} / \mathrm{z}$ ratio. 
The ATOFMS itself is a semi-quantitative instrument. This means that the peak intensities or peak areas of the diverse ions depicted in the mass spectrum do not reflect the actual mass fractions of the components of the respective particles. This is a consequence of several effects: particle transport inside the instrument, the influence of particle properties on the mass-spectrometric detection (e.g., particle size, shape, and morphology), the laser wavelength used, and the laser desorption and ionization process (LDI). Typically, mass spectra of LDI instruments are dominated - if present - by ions with low ionization energy (Zelenyuk and Imre, 2005) such as alkali metals, and the ion intensities of components can vary depending on the chemical matrix of the particle itself (Reilly et al., 2000; Bhave et al., 2002). Additionally, particles can be partially ablated and ionized so that only information on the surface components is obtained (Ge et al., 1998). A clear size and composition bias of the detection efficiency for ultrafine particles using laser desorption mass spectrometry has also been described by Kane and Johnston (2000).

These features of the ATOFMS and the deployed LDI technique are partly reflected in the results presented below. If and how the detection sensitivity of the ATOFMS was biased by matrix effects, the inlet characteristics, and the mass spectrometer operating condition will be discussed accordingly.

\section{$2.5 \quad{ }^{222} \mathrm{Rn}$ and ${ }^{210} \mathrm{~Pb}$}

During ASCOS, the radioactive tracers ${ }^{222} \mathrm{Rn}$ and ${ }^{210} \mathrm{~Pb}$ were measured to identify continental air masses reaching the ship. Radon is an element in the decay chain of uranium, which is ubiquitous in the Earth's crust. Radon can be used as a tracer for air masses that have been in contact with soil. For its detection, the radioactive noble gas ${ }^{222} \mathrm{Rn}$ is separated from the particle-laden air using a filter system. In the instrument, the ${ }^{222} \mathrm{Rn}$ enters a delay chamber where the gas decays to its daughter nuclides that emit alpha radiation. The alpha particles are then counted to infer the ${ }^{222} \mathrm{Rn}$ concentration. A more detailed description can be found in Hutter et al. (1995). The instrument for Radon detection was run by the Finnish Meteorological Institute deploying a US Department of Homeland Security, Environmental Measurements Laboratory, instrument (Paatero et al., 2009).

${ }^{210} \mathrm{~Pb}$ is a radioactive decay product of ${ }^{222} \mathrm{Rn}$ and can be used to determine the travel time of the collected air mass after its last contact with land. The aerosol samples for the ${ }^{210} \mathrm{~Pb}$ analyses were collected on glass fiber filters (type Munktell MGA, Munktell Ahlstrom, Falun, Sweden) using a high-volume sampler. The exposed filters and the field blanks were analyzed in the laboratory 6 months after the campaign for ${ }^{210} \mathrm{~Pb}$ with an automatic alpha/beta analyzer (Mattsson et al., 1996) to determine the ${ }^{210} \mathrm{~Pb}$ activity content. The ${ }^{210} \mathrm{~Pb}$ measurements and analyses were also performed by the Finnish Meteorological Institute (Paatero et al., 2009). The lead data are used in Sect. 3.2 to interpret the aerosol data, i.e., to identify particle source areas.

\subsection{Aerosol Mass Spectrometry and PMF}

A second Aerosol Mass Spectrometer (AMS; Aerodyne Research, Billerica, MA, USA) deployed onboard the Oden was a so-called compact time-of-flight (C-ToF) mass spectrometer. The AMS measured the submicron $(100-500 \mathrm{~nm}$ in diameter) aerosol non-refractory chemical composition. The instrument was located in the aerosol container next to the ATOFMS and shared the same distribution line of ambient air. Similar to the ATOFMS, the particles enter the instrument through an aerodynamic lens that focusses the particles for subsequent aerodynamic sizing and chemical analysis. In contrast to the ATOFMS, the AMS uses flash vaporization and electron impact ionization to produce the gaseous ions that are detected. This allows for a quantitative approach for the chemical mass analysis yet limits the detection to non-refractory material. Results are presented for the average bulk aerosol composition averaged over $5 \mathrm{~min}$ intervals. Details on the specific operation of the AMS during ASCOS can be found in Chang et al. (2011). The AMS was run by the University of Toronto, Canada.

Positive matrix factorization (PMF), a statistics-based analysis tool, was applied on the AMS data for source apportionment and process studies (Ulbrich et al., 2009). The outcome of the PMF analysis are so-called "factors" which describe the most-robust mass spectra. These factors can then be assigned to a certain source based on the prevailing mass-spectrometric peaks, i.e., chemical components. For instance, Chang et al. (2011) obtained four factors best describing the ambient aerosol during ASCOS: a marine biogenic factor, a continental factor, an organic factor, and an emission/contamination factor (cf. Sect. 3.2). Again, details on the specific application of the PMF method on the ASCOS data can be found in Chang et al. (2011).

\subsection{PCASP and aerosol volatility measurement}

A PCASP (passive cavity aerosol spectrometer probe) optical particle spectrometer combined with a programmable tube heater (Brooks et al., 2002, 2007) instrument was used to infer information on the chemical composition and mixing state of the bulk aerosol. The PCASP generates a continuous aerosol size spectrum in the nominal radius range from 0.05 to $1.5 \mu \mathrm{m}$. A tube heater preceded the PCASP, and this heated the sampled air from ambient temperatures to $900^{\circ} \mathrm{C}$. An increase in the heater temperature typically results in changes in either the size and/or the number of aerosol particles based on the volatility of the particles' constituents. Thus, the changes in size spectra with temperature provide information on chemical composition and mixing state. For the analysis herein, only the information on black carbon was used (referred to as "black" carbon since detected optically). 
To obtain the PCASP BC-particle concentration, the number concentrations of particles measured in the temperature interval between 620 and $650{ }^{\circ} \mathrm{C}$ were processed. For temperatures greater than $620^{\circ} \mathrm{C}$ the only types of particulate matter left in the sample are BC, dust, sand, and polymer gels ( $\mathrm{Li}$ et al., 2013), and for temperatures greater than $650^{\circ} \mathrm{C}$ only dust and sand as well as polymer gels remain. The change in spectral shape between these two temperatures is due to the loss of black carbon. The PCASP was located in the aerosol container and operated by the University of Leeds, UK.

\section{Results}

\subsection{Particle type definitions}

ATOFMS data were collected at the OW, MIZ, and IF stations. The total number of particles detected and analyzed by the ATOFMS were 85, 864, 1762 for OW, MIZ, IF, respectively. The low number of hit and chemically analyzed particles compared to other field studies deploying the ATOFMS will be discussed in more detail in Sect. 3.4.

Using ENCHILADA and ART-2a, the cluster algorithm yielded 20, 21, and 22 particle clusters for the OW, MIZ, and IF station, respectively. After screening and re-sorting the individual cluster types, the number of clusters was reduced to 10 overall. This number was considered meaningful by taking similarities of the chemical composition and peak intensities into account. Certain clusters were merged because of an instrumental issue: during some periods, the correlation between ion masses and ion time of flight was unstable from particle-to-particle measurement; that is, the $m / z$ values "jumped" irregularly from spectrum to spectrum by approximately one atomic mass. As a consequence, cluster types were redundant after applying the algorithm. As an example, the most prominent negative peak at $\mathrm{m} / z-97$ appeared sometimes at $m / z-96$ or at -98 in three different clusters, with all other ion masses shifted accordingly. This behavior was most obvious in the negative spectra of the carbonaceous types with equidistant elemental carbon ions. Other low- or singly populated clusters were partly re-sorted and combined based on the mass-spectrometric pattern. A similar method was used for the "outliers", i.e., particles that were not sorted into a cluster by ENCHILADA. Finally, the number of particles in each type was obtained from the clustering process, evaluating these clusters, and adding single-particle mass spectra manually when necessary. The procedure was possible due to the overall low numbers of particles analyzed; therefore mass spectra could be screened and sorted individually. The obtained particle types are listed in Table 1 and described in the following.

\section{Inorganic carbonaceous types}

Here, four particle types (1a, b, c, and d) obtained from the clustering procedure are presented. They all show similar mass-spectrometric pattern but can still be distinguished by some minor peaks and different peak intensities. Pronounced peaks of these four types include elemental carbon (EC), potassium, sulfate, ions of minor intensities representing organic carbon (OC) mass fragments, nitrate, multiple PAHs (polycyclic aromatic hydrocarbons) found at large mass-to-charge ratios $(m / z>100)$, and metal elements. The mass spectra of three carbonaceous particle types/clusters are shown in Fig. 2. The upper panel depicts the most prominent particle type detected, in the following termed ECOC$K$-sulfate type. The positive center of the cluster contains a dominant potassium peak at $\mathrm{m} / z+39\left({ }^{39} \mathrm{~K}^{+}\right.$or ${ }^{39 / 41} \mathrm{~K}^{+}$ when including its isotope). Moreover, this type is characterized by carbon clusters ions at ${ }^{12 \mathrm{n}} \mathrm{C}_{\mathrm{n}}^{+}$(e.g., ${ }^{12} \mathrm{C}^{+},{ }^{24} \mathrm{C}_{2}^{+}$, ${ }^{36} \mathrm{C}_{3}^{+}$, etc.); hydrocarbons such as ${ }^{12 n} \mathrm{C}_{\mathrm{n}} \mathrm{H}^{+},{ }^{27} \mathrm{C}_{2} \mathrm{H}_{3}^{+}$, and ${ }^{29} \mathrm{C}_{2} \mathrm{H}_{5}^{+}$; and a peak at ${ }^{43} \mathrm{C}_{2} \mathrm{H}_{3} \mathrm{O}^{+}$, a marker for oxidized organics. Hydrocarbons and the oxidized organic ion are used as tracers for OC (Silva and Prather, 2000; Pastor et al., 2003). The negative center is dominated by sulfate ions at ${ }^{97} \mathrm{HSO}_{4}^{-},{ }^{195} \mathrm{H}\left(\mathrm{HSO}_{4}^{2-}\right),{ }^{80} \mathrm{SO}_{3}^{-}$, and ${ }^{96} \mathrm{SO}_{4}^{-}$, as well as the marker for ocean-derived biogenic sulfur: methanesulfonic acid (MSA, ${ }^{95} \mathrm{CH}_{3} \mathrm{SO}_{3}^{-}$). The characteristic pattern of EC fragments ${ }^{12 \mathrm{n}} \mathrm{C}_{\mathrm{n}}^{-}$are displayed in the negative center as well. Particle type 1b, ECOC-K-sulfate-CN, can be distinguished from type 1a by peaks that are more pronounced at ${ }^{26} \mathrm{CN}^{-}$ and ${ }^{42} \mathrm{CNO}^{-}$but of minor intensity compared to the $\mathrm{K}-\mathrm{CN}-\mathrm{S}$ type as discussed below. Particle type 1c (see Supplement Fig. S1) is characterized by repetitive peaks from hydrocarbons/OC; oxygenated high-molecular-mass compounds; indicators of strong aromatic signatures $\left({ }^{51} \mathrm{C}_{4} \mathrm{H}_{3}^{+},{ }^{63} \mathrm{C}_{5} \mathrm{H}_{3}^{+}\right.$, ${ }^{77} \mathrm{C}_{6} \mathrm{H}_{5}^{+}$; McLafferty and Turecek, 1993); and PAHs found at higher atomic masses (Gross et al., 2000; Silva and Prather, 2000; Dall'Osto et al., 2012), termed ECOC-PAHs. Type 1d, in contrast, shows a similar inorganic ECOC pattern compared to type $1 \mathrm{a}$ and $1 \mathrm{~b}$ but contains additional metal ions mainly detected at ${ }^{7} \mathrm{Li}^{+}$, and/or ${ }^{27} \mathrm{Al}^{+} / \mathrm{C}_{2} \mathrm{H}_{3}^{+}$, and/or ${ }^{51} \mathrm{~V}^{+}$, and its oxide ${ }^{67} \mathrm{VO}^{+}$, and/or ${ }^{54 / 56} \mathrm{Fe}^{+}$, and/or Mo (cluster around $m / z+98$ ), and/or ${ }^{107 / 109} \mathrm{Ag}^{+}$, and/or ${ }^{138} \mathrm{Ba}^{+}$. This type is termed ECOC-K-sulfate-metals.

\section{Sea salt types}

The sea salt clusters are grouped into three different particle types. Cluster $2 \mathrm{a}$ is pure sea salt, $\mathrm{Na}_{\mathrm{x}} \mathrm{Cl}_{\mathrm{y}}$, where almost all of the peaks are attributable to sodium chloride. The positive cluster centers show ${ }^{23} \mathrm{Na}^{+},{ }^{39} \mathrm{~K}^{+},{ }^{46} \mathrm{Na}_{2}^{+}$, ${ }^{81 / 83} \mathrm{Na}_{2} \mathrm{Cl}^{+}$, and ${ }^{139 / 141} \mathrm{Na}_{3} \mathrm{Cl}_{2}^{+}$. In the negative cluster, peaks are present for ${ }^{35 / 37} \mathrm{Cl}^{-},{ }^{58 / 60} \mathrm{NaCl}^{-},{ }^{93 / 95 / 97} \mathrm{NaCl}_{2}^{-}$, and ${ }^{151 / 153 / 155} \mathrm{Na}_{2} \mathrm{Cl}_{3}^{-}$(see, for example, Pastor et al., 2003; 
Table 1. Most prominent particle types obtained using ENCHILADA and ART-2a. Bold-face letters mark the main aerosol types.

\begin{tabular}{|c|c|c|}
\hline Cluster number & Cluster type & Cluster characteristics \\
\hline 1 & Inorganic carbonaceous types & \\
\hline $1 \mathrm{a}$ & ECOC-K-sulfate & pronounced ${ }^{12 \mathrm{n}} \mathrm{C}_{\mathrm{n}}^{+/-}$, OC ions, ${ }^{39} \mathrm{~K}^{+},{ }^{97} \mathrm{HSO}_{4}^{-}$ \\
\hline $1 b$ & ECOC-K-sulfate-CN & pronounced ${ }^{26} \mathrm{CN}^{-}$and minor ${ }^{42} \mathrm{CNO}^{-}$; compare to $1 \mathrm{a}$ \\
\hline $1 \mathrm{c}$ & ECOC-PAHs & multiple hydrocarbons and peaks at $m / z>100$ \\
\hline $1 d$ & ECOC-K-sulfate-metals & similar to $1 \mathrm{a}$ and $1 \mathrm{~b}$, including diverse metal ions \\
\hline 2 & Sea salt types & \\
\hline $2 \mathrm{a}$ & $\mathrm{NaCl}$ pure & pure $\mathrm{Na}$ and $\mathrm{Cl}$ \\
\hline $2 b$ & $\mathrm{NaCl}$ mixed & $\mathrm{NaCl}_{\mathrm{x}} \mathrm{NO}_{\mathrm{y}}$ \\
\hline $2 \mathrm{c}$ & $\mathrm{NaCl}$ aged & $\mathrm{NaNO}_{3}$ \\
\hline 3 & K-CN-sulfate type & major peaks at ${ }^{39} \mathrm{~K}^{+}$and ${ }^{26} \mathrm{CN}^{-}$ \\
\hline 4 & Metal type & distinct peaks representing $\mathrm{Li} / \mathrm{Fe} / \mathrm{Ba} / \mathrm{V} / \mathrm{Al}$ \\
\hline 5 & Soil dust type & $\begin{array}{l}\text { distinct peaks representing } \mathrm{Ca}, \mathrm{Al} \text {, or } \mathrm{Fe} \\
\text { and biological markers }\end{array}$ \\
\hline
\end{tabular}
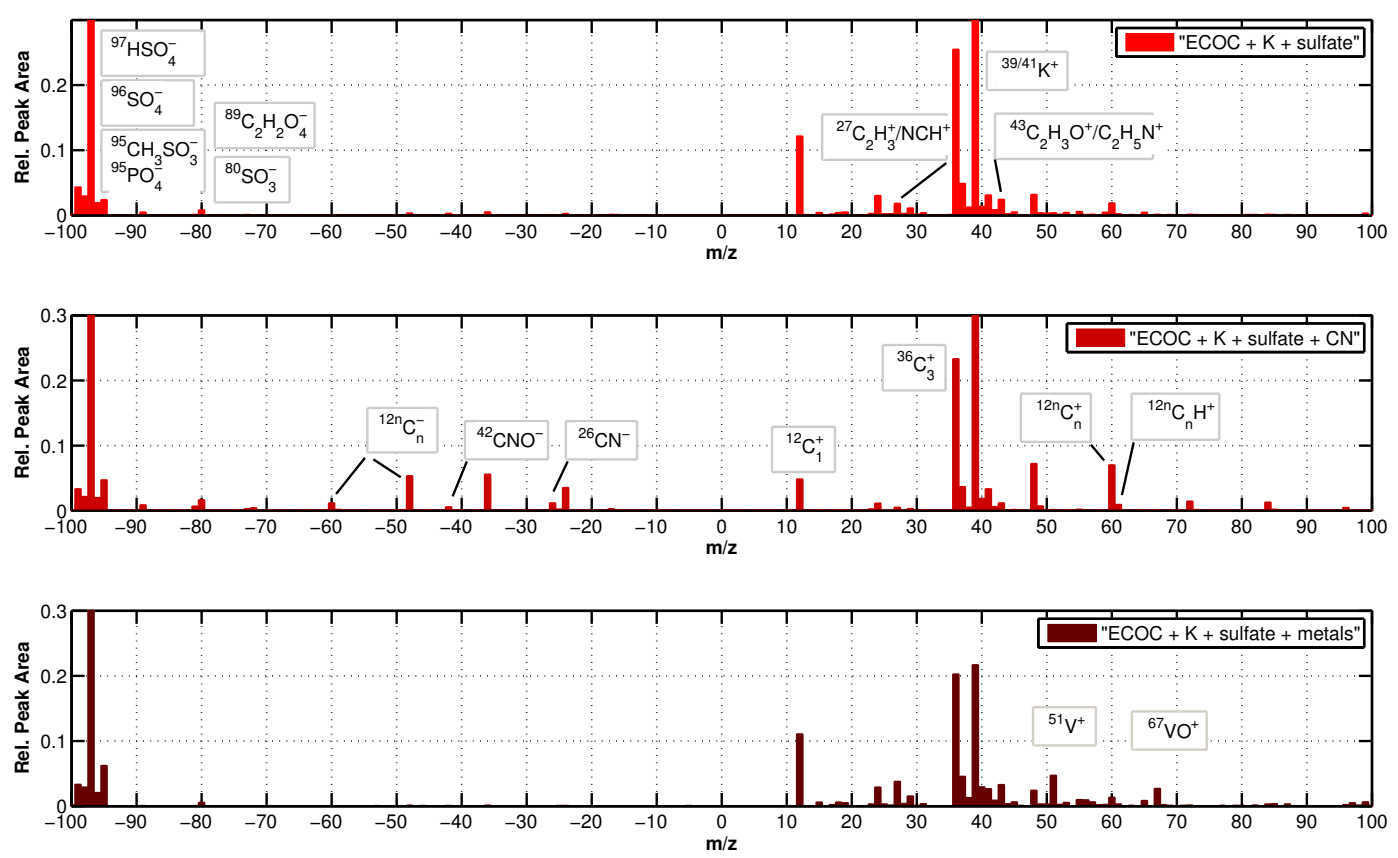

Figure 2. Mass spectra of the inorganic carbonaceous particles types obtained using the cluster algorithm ENCHILADA. The upper panel depicts the most prominent $E C O C$ - $K$-sulfate type 1a. The middle one depicts the ECOC-K-sulfate-CN type $1 \mathrm{~b}$ subject to more pronounced peaks at ${ }^{12 \mathrm{n}} \mathrm{C}_{\mathrm{n}}^{+},{ }^{12 \mathrm{n}} \mathrm{C}_{\mathrm{n}}^{-},{ }^{26} \mathrm{CN}^{-}$, and ${ }^{42} \mathrm{CNO}^{-}$. The lower panel shows type $1 \mathrm{~d}$ with similar mass-spectrometric pattern including traces of metals. The relative peak areas of the $\mathrm{HSO}_{4}^{-}$ion are 0.83 (upper panel), 0.63 (middle panel), and 0.79 (lower panel), and those of $\mathrm{K}^{+}$are 0.31 (upper panel) and 0.37 (middle panel). A peak at $\mathrm{m} / z-195$ assigned to $\mathrm{H}_{3}\left(\mathrm{SO}_{4}\right)_{2}^{-}$appears in all three spectra but, for clarity, is not shown.

Dall'Osto et al., 2004). Chemical aging changes the composition of atmospheric sea salt aerosols as it can react with acidic gases such as $\mathrm{HNO}_{3(\mathrm{~g})}$ and $\mathrm{H}_{2} \mathrm{SO}_{4(\mathrm{~g})}$ to form nitrate and sulfate and release hydrogen chloride to the gas phase (Harrison et al., 1994; Pakkanen et al., 1996; Gard et al., 1998). Cluster $2 b$ represents a mixed sea salt type, $\mathrm{Na}_{\mathrm{x}} \mathrm{Cl}_{\mathrm{y}}$ nitrate-sulfate, that, in addition to the sodium chloride peaks, contains peaks from nitrate, sulfur and sulfate (e.g., ${ }^{46} \mathrm{NO}_{2}^{-}$, $\left.{ }^{62} \mathrm{NO}_{3}^{-},{ }^{80} \mathrm{SO}_{3}^{-},{ }^{96} \mathrm{SO}_{4}^{-}\right)$, and $(\mathrm{NaCl}) \mathrm{NO}_{\mathrm{x}}$ clusters. Further aging replaces the $\mathrm{Cl}$ molecules in the latter compounds with nitrate, resulting in $\mathrm{Na}_{\mathrm{x}} \mathrm{NO}_{\mathrm{y}}$ combinations at $m / z+108$, -131 , and -141 (Gard et al., 1998; Dall'Osto et al., 2004). These ions were present in cluster type 2c: aged sea salt, $\mathrm{Na}_{\mathrm{x}} \mathrm{Cl}_{\mathrm{y}}$-nitrate- $\mathrm{Na}_{\mathrm{x}} \mathrm{NO}_{\mathrm{y}}$-sulfate. The mass spectra of the sea salt clusters are presented in Fig. S5 in the Supplement. 


\section{$\mathrm{K}$-CN-sulfate type}

Cluster type 3 represents a particle type with a dominant peak at ${ }^{26} \mathrm{CN}^{-}$(sometimes including ${ }^{42} \mathrm{CNO}^{-}$), including a pronounced peak at ${ }^{97} \mathrm{HSO}_{4}^{-}$and less significant peaks at the sulfur markers $m / z-48,-64,-80$, and -96 . No additional nitrate is present in the form of ${ }^{46} \mathrm{NO}_{\mathrm{x}}^{-}$. The only peak in the positive spectrum is ${ }^{39} \mathrm{~K}^{+}$with the possibility of ${ }^{40} \mathrm{Ca}^{+}$ being masked (see below). None or only minor fragments of EC and OC are present in the negative spectrum. For reference, Fig. S2 in the Supplement depicts an example of a single-particle mass spectrum of this type.

\section{Metal type}

Cluster type 4 represents a particle type with multiple pronounced metal peaks much more dominant than found in type $1 \mathrm{~d}$. The metal ions represent the elements $\mathrm{Li}, \mathrm{Al}, \mathrm{V}, \mathrm{Fe}$, $\mathrm{Mo}, \mathrm{Ag}$, and $\mathrm{Ba}$. $\mathrm{Al}$ and $\mathrm{AlO}$ at $m / z+27$ and +43 interfered with the OC markers ${ }^{27} \mathrm{C}_{2} \mathrm{H}_{3}^{+}$and ${ }^{43} \mathrm{C}_{2} \mathrm{H}_{3} \mathrm{O}^{+}$and cannot be unambiguously identified. For reference, Fig. $\mathrm{S} 3$ in the Supplement depicts an example of a single-particle mass spectrum of this type.

\section{Soil dust type}

Cluster type 5 represents a particle type containing pronounced peaks at ${ }^{40} \mathrm{Ca}^{+},{ }^{56} \mathrm{CaO}^{+}$, and ${ }^{57} \mathrm{CaOH}^{+}$along with traces of sodium, magnesium, aluminum, and nitrates. Cadominated dust particles could be distinguished from AlSi-dominated dust particles; however, they were not sorted exclusively into different subgroups because of the small number of particles detected. Most of the mass spectra also contained potential markers for biological material, i.e., ion peaks representing ${ }^{26} \mathrm{CN}^{-},{ }^{42} \mathrm{CNO}^{-}$, and ${ }^{79} \mathrm{PO}_{4}^{-}$(Creamean et al., 2013). For reference, Fig. S4 in the Supplement depicts an example of a single-particle mass spectrum of this type.

\section{Unidentified particles}

Particles that were not clustered into any of the types listed above remained in this group. A large fraction of these particles are characterized by mass spectra only showing a positive ion signal.

\subsection{Particle types, their relative abundance, and potential sources}

In this section we discuss the abundance of the particle types detected during ASCOS and described in the section above. Emphasis is placed on the results from the ice floe station as this measurement period represents the longest of the three stations with the highest number of analyzed particles. Moreover, the measurements at the ice floe station are novel.
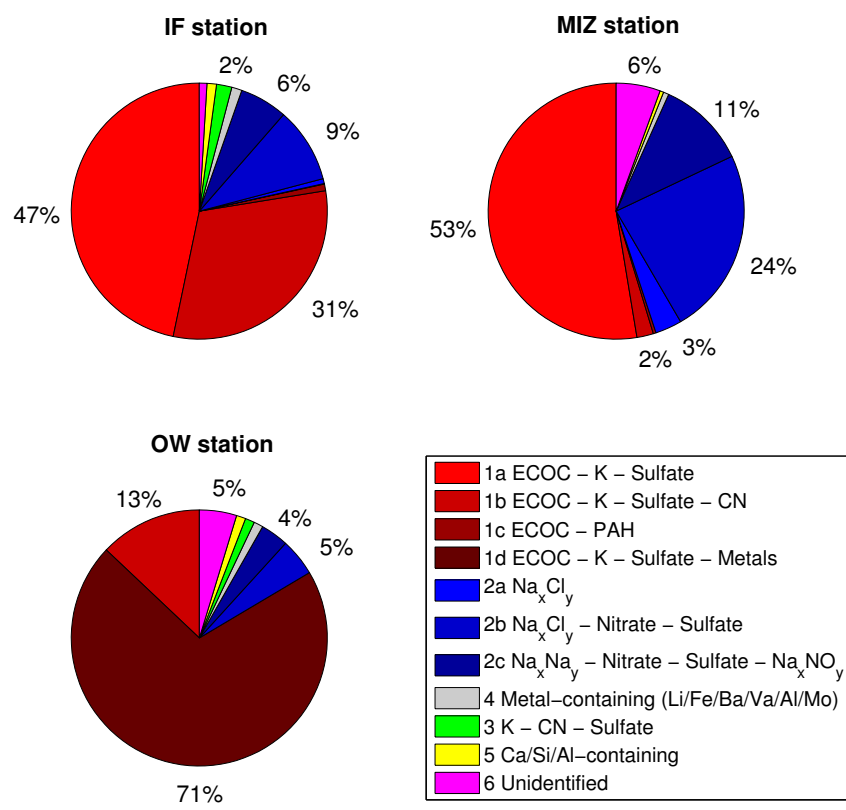

Figure 3. Number-based pie chart of the aerosol clusters for the IF, MIZ and OW station. A fraction of less than $1 \%$ is not labeled in the figure for clarity.

The pie charts in Fig. 3 show the abundance of the different particle types sorted according to the three measurement stations, i.e., ice floe, marginal ice zone, and open water station. The percentage given represents the number-based fraction of the respective particle type and relates to the total number of "hit" particles at each station (IF: 1762; MIZ: 864; OW: $85)$. For clarity, a fraction of less than $1 \%$ is not labeled in the figure.

\subsubsection{Ice floe station}

The dominant particle type measured at the ice floe was the ECOC-K-sulfate type (1a) with a fraction of $47 \%$ of all particles analyzed in the size range covered by the ATOFMS. The sum of the fractions of all inorganic carbonaceous types (1a-1d) is about $80 \%$. Sea salt particles made up a fraction of approximately $16 \%$. Almost all of the sea salt particles acquired secondary compounds such as nitrate $\left({ }^{62} \mathrm{NO}_{3}^{-}\right)$ and sulfate $\left({ }^{97} \mathrm{HSO}_{4}^{-}\right)$in place of chloride, indicating an atmospheric aging process of the particles prior to reaching the ship (9\% type $2 \mathrm{~b}$ and $6 \%$ type $2 \mathrm{c}$; see Sect. 3.1 ). Only a fraction of less than $2 \%$ showed signatures of "fresh" or "pure" sea salt. Less than $1 \%$ of the analyzed particles were metal containing. About $2 \%$ remained unidentified. Particles of type 1c (ECOC-PAHs) show a similar pattern to particles sampled and analyzed from the Oden's exhaust and occurred during a short and confined time interval. Therefore we assume that type 1c contains pollution particles from our own ship that have not been screened out correctly. These particles will not be discussed any further. 


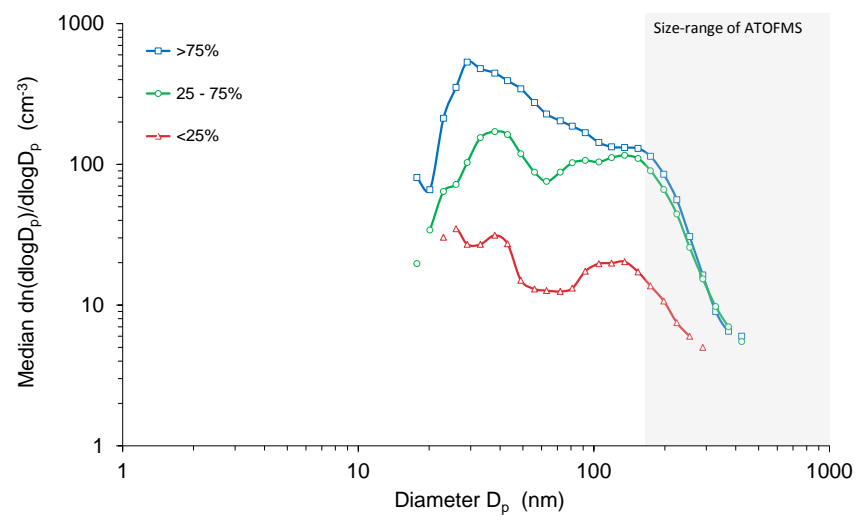

Figure 4. Mean number size distributions in three subpopulations of hourly averaged ASCOS 2008 in-ice data. Plotted are the total number concentrations in the percentiles of less than $25 \%$, between 25 and $75 \%$, and larger than $75 \%$. Image modified from Heintzenberg and Leck (2012).

It has to be noted in general that the majority of the particles in the marine boundary layer during ASCOS were too small to be detected by the ATOFMS. Figure 4 depicts the median number size distribution of the 2008 data collected within the central pack ice (Heintzenberg and Leck, 2012). Shown are the percentiles of the total number concentration that are less than $25 \%$, between 25 and $75 \%$, and larger than $75 \%$. The approximate size range of the ATOFMS is marked by the grey shaded area (not accounting for the upper size limit). The lower size threshold is derived from converting the lower cut-off diameter of $\sim 200 \mathrm{~nm}$ into its mobility equivalent (for more details see Sect. 3.4). Based on this graph, the ATOFMS would only have detected the tail of the accumulation-mode particles (80-1000 nm diameter size range with a maximum at $\sim 150 \mathrm{~nm}$ ) and none of the smaller, Aitken-mode particles.

The similarities of the basic mass-spectrometric pattern of type $1 \mathrm{a}, 1 \mathrm{~b}$, and $1 \mathrm{~d}$ concerning their inorganic sulfate, potassium, and EC/OC-related peaks generally point to a common source of the particles. This is also supported by the analysis of the temporal trends of the $1 \mathrm{a}$ and $1 \mathrm{~b}$ cluster type particles as outlined in Sect. 3 and Fig. S6 if the Supplement. The differences in peak intensities of the EC and OC markers between the clusters probably stem from a combination of real differences in the masses of the particle constituents combined with matrix effects resulting from the laser ablation/ionization process as outlined above. The variable ratios in the spectral peaks of the particles within one cluster indicate an internal mixture of these components. Based on the characteristic ion signals of the carbonaceous particle type 1, its source likely is biomass or biofuel burning, either of anthropogenic or natural origin. Combustion processes are the major source of primary elemental carbon particles in the atmosphere. The elemental carbon series are apparent in the inorganic ECOC-type spectra in peaks at ${ }^{12 n} C_{n}^{-}$and ${ }^{12 n} C_{n}^{+}$, with $n$ up to 6 , and often more pronounced with $n$ up to 12 (mainly type 1b). The difference in the intensities of the elemental carbon core signatures could be an indication of variable coating thicknesses by secondary material, and thus different atmospheric aging times. The organic carbon content is either primary or secondary due to internal mixing with OC particles or organic gas-phase components condensed on the preexisting particles during atmospheric processing. The peak at $m / z+43$ is commonly used as a marker ion $\mathrm{C}_{2} \mathrm{H}_{3} \mathrm{O}^{+}$ representing aged organics (Qin and Prather, 2006; Qin et al., 2012); however, it can also be due to $\mathrm{C}_{3} \mathrm{H}_{7}^{+}$or $\mathrm{C}_{2} \mathrm{H}_{5} \mathrm{~N}^{+}$. Another tracer for highly oxidized organics, oxalate $\left(\mathrm{C}_{2} \mathrm{O}_{4} \mathrm{H}_{2}^{-}\right.$ at $m / z-89)$, is periodically present in the spectra as well. The potassium peak is a typical marker for biomass burning aerosol and/or wood smoke (Silva et al., 1999; Qin and Prather, 2006; Friedman et al., 2009), and can be found in either of the particle clusters of type $1 \mathrm{a}, \mathrm{b}$, and d. Marker peaks for levoglucosan, another biomass burning indicator and typically represented by the characteristic ions for formate ${ }^{45} \mathrm{CHO}_{2}^{-}$and acetate ${ }^{59} \mathrm{C}_{2} \mathrm{H}_{3} \mathrm{O}_{2}^{-}$(Silva et al., 1999; Qin and Prather, 2006), were, however, not present.

The particles referred to as biomass burning aerosol contained sulfur, as indicated by the presence of sulfate ions at $m / z-64,-80,-96,-97$, and $-195\left(\mathrm{SO}_{2}^{-}, \mathrm{SO}_{3}^{-}, \mathrm{SO}_{4}^{-}\right.$, $\mathrm{HSO}_{4}^{-}$, and $\mathrm{H}_{3}\left(\mathrm{SO}_{4}\right)_{2}^{-}$, respectively). These particles either exhibited atmospheric aging and/or coagulation and agglomeration with sulfur-containing particles at the point of combustion or the sulfur stems from the burned biomass itself. Potassium sulfate has been detected as a typical constituent of emission from wood combustion (Pagels et al., 2003, 2013). Another indicator of atmospheric aging is the presence of a minor peak at $\mathrm{m} / z+213$ that corresponds to $\mathrm{K}_{3} \mathrm{SO}_{4}^{+}$. For combustion-related particles, Gaudichet et al. (1995) report an evolution from $\mathrm{KCl}$ to $\mathrm{K}_{3} \mathrm{SO}_{4}^{+}$with increasing distance from the emission source; however the presence of chlorine and sulfate depends on the combustion temperature itself. $\mathrm{K}_{3} \mathrm{SO}_{4}^{+}$could be identified in approximately $13 \%$ of the IF particle spectra. None or only small traces of nitrate were found in the type 1 particles. This is consistent with past findings (Leck and Persson, 1996) and ASCOS results from the aerosol mass spectrometer (Chang et al., 2011) showing very low particulate nitrate mass concentrations around or below the detection limit of the instrument of approximately $0.008 \mu \mathrm{gm}^{-3}$ for most of the ice floe measurement period. Particle type $1 \mathrm{~b}$ looks similar in nature to type 1a; however, the mass spectra show an elevated signal of ${ }^{26} \mathrm{CN}^{-}$and ${ }^{42} \mathrm{CNO}^{-}$. Silva et al. (1999) report on singleparticle mass spectra of biomass burning aerosol that include peaks of variable intensity of $\mathrm{CN}^{-}$and $\mathrm{CNO}^{-}$. The presence of $\mathrm{CN}^{-}$and $\mathrm{CNO}^{-}$could be an indicator of the simultaneous occurrence of carbon and nitrogen in the particle (Mauney et al., 1984; Kolaitis et al., 1989), or it could also result from amines and amino groups due to fragmentation of biological material. Intense peaks of ${ }^{26} \mathrm{CN}^{-}$and 

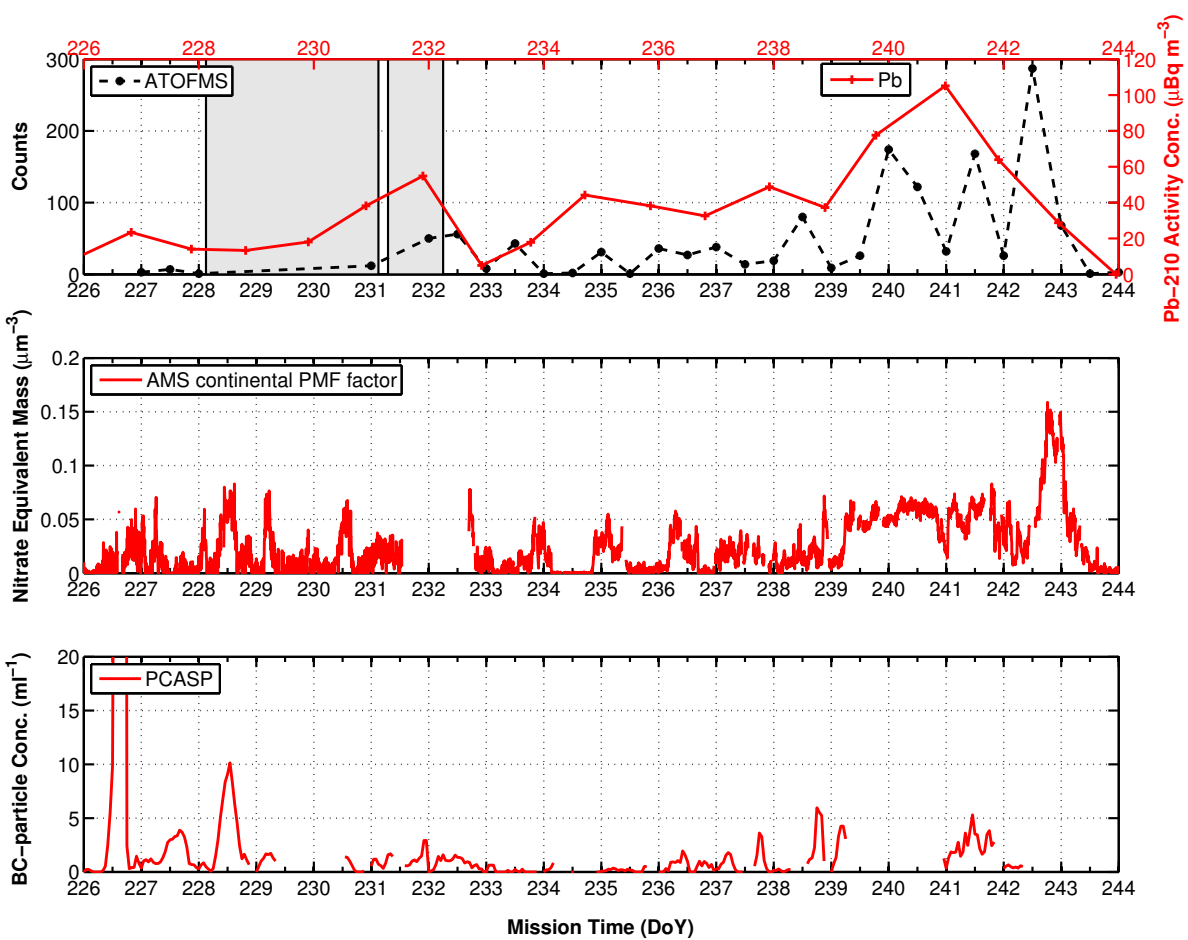

Figure 5. Timeline of $12 \mathrm{~h}$-averaged ATOFMS type 1 particle counts and ${ }^{210} \mathrm{~Pb}$ activity concentration (upper panel), AMS-derived continental PMF factor (middle panel), and PCASP BC-particle concentration (lower panel). Time periods when the ATOFMS was not or only partially operational are depicted as grey shaded boxes in the upper panel.

${ }^{42} \mathrm{CNO}^{-}$have been found in particles of biological origin (Fergenson et al., 2004; Pratt et al., 2009; Creamean et al., 2013) and are discussed in Sect. 3.3. Particle type 1b could then represent an internal mixture of type 1a particles and type $\mathrm{K}-\mathrm{CN}-\mathrm{S}$, or other, non-identified C- and N-dominated particles. Some fraction of the type 1 particles contained methanesulfonic acid (MSA, indicated by a peak at $\mathrm{m} / z-95$ $\left(\mathrm{CH}_{3} \mathrm{SO}_{3}^{-}\right)$), a photooxidation product of dimethyl sulfide (DMS). MSA has no known anthropogenic source, making it a useful tracer for ocean-derived biogenic sulfur. MSA was also detected by Chang et al. (2011), with its mass mainly connected to a "marine biogenic factor" obtained from PMF analysis (cf. Sect. 2.6). The internal mixing of MSA with the inorganic ECOC types suggests that the measured air masses passed over biologically active waters where they incorporated the MSA-precursor gases such as DMS. These were then oxidized to MSA and sulfate, which subsequently condensed on the particles before being detected at the location of the ship. The marine biogenic factor of Chang et al. (2011) was present for most of the time during the IF measurement period, which is consistent with our findings (for a more detailed discussion please refer to the cited publication). Note that the assignment of $m / z-95$ to MSA is ambiguous as the ion peaks of $\mathrm{NaCl}_{2}^{-}$and $\mathrm{PO}_{4}^{-}$potentially interfere.

\section{Time series of inorganic ECOC type 1 particles}

To explore the air mass source of type 1 particles in more detail, the time series of ATOFMS counts (i.e., the number of obtained mass spectra with time) was evaluated. The time series of type 1 particle counts was compared to that of (a) ${ }^{210} \mathrm{~Pb}$, (b) the AMS continental factor obtained from PMF analysis (Chang et al., 2011), and (c) BC-particle counts deduced from PCASP measurements (cf. Sects. 2.5 and 2.7). The tracer ${ }^{210} \mathrm{~Pb}$ is used as an indicator of air that has had contact with land/soil (and the age of the air since contact). The AMS continental factor is assigned to aerosols with typical mass-spectrometric fingerprints of continental regions (Zhang et al., 2007). The time series from DoY 226 (13 August 2008) to DoY 244 (31 August 2008) of the inorganic ECOC type is shown in the upper panel of Fig. 5 together with the ${ }^{210} \mathrm{~Pb}$ data. The measurement points of the ATOFMS data depict the $12 \mathrm{~h}$ sum of type $1 \mathrm{a}, 1 \mathrm{~b}$, and $1 \mathrm{~d}$ particle counts (the individual $1 \mathrm{~h}$ time series can be found in the Supplement). The ATOFMS time series shows an elevated number of type 1 cluster counts after DoY 238. Due to the generally low number of counts and the large averaging time of $12 \mathrm{~h}$ applied, only a tendency of increasing particle counts from the beginning of the IF measurement period to the end can be stated. This includes four peak periods around DoY 238.5, 240.5, 241.5, and 242.5. Periods of low counts are between DoY 227 and 228, 234 and 234.5, and 243.5 


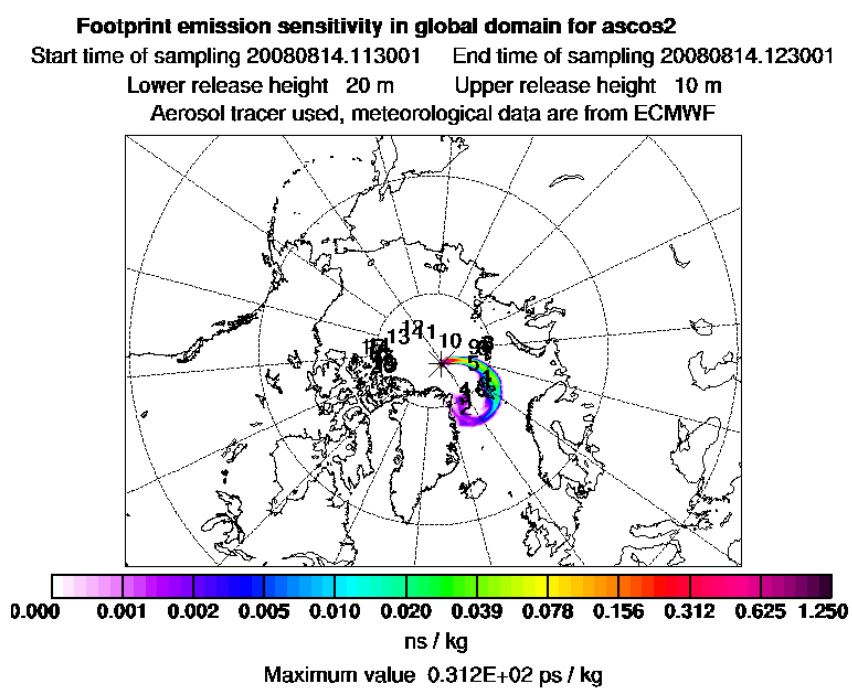

Figure 6. Footprint potential emission sensitivity for $14 \mathrm{Au}$ gust 2008 (DoY 227) obtained from FLEXPART. The receptor, i.e., Oden, is marked with an asterisk. The numbers (in days backward) plotted on top of the map represent a daily retroplume product that roughly indicates the transport speed. The emission sensitivity (in units of $\mathrm{s} \mathrm{kg}^{-1}$ ) is proportional to the particle residence time in a grid cell of the "footprint layer" and measures the simulated mixing ratio at the receptor that a source of unit strength $\left(1 \mathrm{~kg} \mathrm{~s}^{-1}\right)$ in the cell would produce.

and 244. The ${ }^{210} \mathrm{~Pb}$ measurements show a period of elevated concentration between DoY 239 and 243, slightly increasing from DoY 233. In general, the progressions of both curves are comparable. The peak period of the ${ }^{210} \mathrm{~Pb}$ activity concentration around DoY 241 correlates with the period of increased ATOFMS cluster type 1 counts starting from DoY 238.5. The minimum ATOFMS count number at the beginning of the time period shown is reflected by a low ${ }^{210} \mathrm{~Pb}$ activity concentration.

The time series of the AMS PMF continental factor shows a high signal between DoY 239.2 and 243.5, with a significant peak around DoY 242.5-243.5. This period of high signal correlates more closely with the ATOFMS period of increased type 1 count number from DoY 238.5 to 243 , and the maximum occurs in both time series at the end of the high signal period around DoY 243. The similarities between the ATOFMS type 1 particles' time series and that of the continental factor supports the assumption that the type 1 cluster particles stem from biomass burning/biofuel burning sources of continental origin.

Additionally, BC-particle concentrations were deduced from PCASP measurements that were performed on the same inlet system. Since the ATOFMS type 1 cluster particles include a clear signature of EC, the BC-particle concentration measured by the PCASP is ideal for intercomparison. The BC-particle concentration was deduced from the PCASP data as described in Sect. 2.7. Note that the peri-

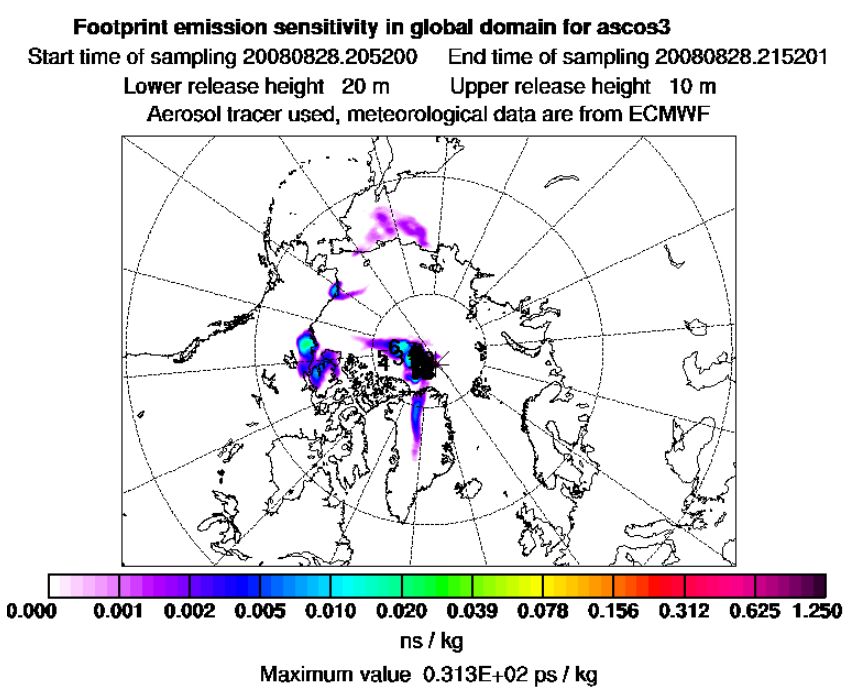

Figure 7. Footprint emission sensitivity for 28 August 2008 (DoY 241) obtained from FLEXPART.

ods in Fig. 5 with no PCASP data do not necessarily indicate that the instrument was not operating - it was operating but the aerosol composition was such that no BC signal (the detection limit of the PCASP BC-core size corresponds to a particle size of approximately $100 \mathrm{~nm}$ ) was detected. The PCASP, however, was not operational during the high signal period seen in the ATOFMS, the ${ }^{210} \mathrm{~Pb}$, and the AMS data (DoY > 242.7), and also not during the time window DoY 239.25-241 (B. Brooks, personal communication, 2013). The only period of PCASP data available during the period of elevated ATOFMS counts between DoY 239 and 243 covers a period around DoY 241 with observed BCparticle concentrations of up to $5 \mathrm{~mL}^{-1}$. This value is significantly larger than those of the periods with minimal concentrations $<1 \mathrm{~mL}^{-1}$ (e.g., DoY 233-236). The maximum BC concentration was observed on DoY $226\left(\sim 250 \mathrm{~mL}^{-1}\right)$. This period, however, correlates with neither a maximum in the AMS continental factor nor with the ${ }^{210} \mathrm{~Pb}$ data and is due to pollution from the ship, as confirmed by the pollution record (B. Brooks, personal communication, 2013). In contrast, a second maximum on DoY $228\left(\sim 10 \mathrm{~mL}^{-1}\right)$ correlates with a peak in the AMS continental factor. Unfortunately, the ATOFMS did not measure during the latter peak periods of the PCASP's BC-particle concentrations due to instrumental problems. Nevertheless, low BC concentrations observed by the PCASP are reflected in low numbers of ATOFMS type 1 particle counts.

\section{Origin of particles}

In summary, the analysis of the particle type $1 \mathrm{a}, \mathrm{b}, \mathrm{d}$ presented herein (mass spectrometric pattern, elevated occurrence during the time period DoY 239.5-243 (26 August 
2008-30 August 2008), elevated signals in the AMS continental factor and the ${ }^{210} \mathrm{~Pb}$ activity concentration) suggests that the air originates from continental sources. ${ }^{222} \mathrm{Rn}$ observations also support this interpretation. Between DoY 241 22:00 UTC and DoY 242 10:00 UTC the ${ }^{222} \mathrm{Rn}$ activity concentration doubled from a background level of about $0.1 \mathrm{~Bq} \mathrm{~m}^{-3}$ and reached a maximum value of $0.32 \mathrm{~Bq} \mathrm{~m}^{-3}$. A detailed analysis of the meteorological conditions during the period of DoY 240 to DoY 243 by Shupe et al. (2013) and Kupiszewski et al. (2013) further supports this interpretation. The authors of both papers report on the co-concurrent presence of continentally sourced air of elevated particle concentration in the upper boundary layer (400-700 $\mathrm{m}$ altitude; Kupiszewski et al., 2013) and meteorological conditions allowing for this air to be mixed down to the surface. During DoY 242 (29 August) our sampling coincided with the recoupling and turbulent mixing between a shallow $(\sim 150 \mathrm{~m}$ deep) surface-based mixed layer in the lower part of the boundary layer with a separate mixed layer located in the upper part of the boundary layer - the upper half of which contained stratocumulus clouds. Back trajectories analyzed by the authors using the Hybrid Single Particle Lagrangian Integrated Trajectory Model (HYSPLIT; Draxler and Rolph, 2011) suggest that the air in the upper boundary layer had come from the Canadian Archipelago whereas that in the lowest $100 \mathrm{~m}$ had been over the ice for at least 10 days. In this way, air probably containing biomass burning aerosols became entrained into the top of the clouds and mixed into the surface mixed layer, allowing for it to be observed at the ship. A meteorological setting that resulted in such a "pollution event" was observed only once during the entire ice drift period.

Only limited support for an enhanced influence of continental aerosol during that time period is given by backward simulations of the Lagrangian particle dispersion model FLEXPART (Stohl et al., 1998; Stohl, 2006; Law and Stohl, 2007) analyzed herein. One FLEXPART product, the "footprint potential emission sensitivity", accounts for the air parcel's origin and its source strength averaged over the lowest $100 \mathrm{~m}$ above the surface, including aerosol-like removal by dry and wet deposition. Therefore, this product gives a good indication of where anthropogenic particle emissions may have accumulated in an air mass and transported to the ship because these emissions are mainly emitted in the surface layer of continents. Figures 6 and 7 depict the footprint potential emission sensitivity for two different situations: the first shows a simulation ending on DoY 227.5 (14 August) with low or no influences of air from land masses. The second, in comparison, shows a simulation ending on DoY 241.92 (28 August 21:52:01 UTC), i.e., a day that falls into the above-discussed period of elevated type 1 cluster particles. The footprint depicted on the simulation for DoY 241 is larger on the continents but includes only small parts of Greenland, northernmost Canada, Alaska, and Russia as pos- sible source regions for the observed carbonaceous aerosol type.

In summary, aerosol particles or their precursors in upper air layers could potentially be advected over long distances and later be entrained into the surface mixed layer of the boundary layer through the cloud top by cloud-induced mixing (e.g., Shupe et al., 2013). If present, such a process could help explain "residual" particles of inorganic carbonaceous type 1 particles detected before DoY 239. Kupiszewski et al. (2013) summarized the results from aerosol profiling using a helicopter stationed onboard the Oden for a number of episodes during ASCOS. For instance, one episode involved an elevated plume aloft in the free troposphere with high concentrations of accumulation-mode particles that they suggest to have been caused by Siberian forest fires and subsequent long-range transport. The authors, however, conclude that these long-range-transported plumes are unlikely to be mixed down to the boundary layer.

Furthermore, aged sea salt particles were detected while at the ice drift station, which is in agreement with results from the previous icebreaker expeditions (Leck et al., 2002). The temporal trends of type $2 \mathrm{~b}$ (mixed $\mathrm{NaCl}$ ) and type $2 \mathrm{c}$ (aged $\mathrm{NaCl}$ ) particle counts show strong similarities (see Fig. S5 in the Supplement), indicating a common transport path and origin of the particles of both types before reaching the ship. The advanced "chemical age" of type $2 \mathrm{c}$ suggests that these particles resided and thus aged for a longer time over the pack ice before being detected at the Oden. Sea salt particles are generated at the sea-air interface by bubble-bursting mechanisms (Blanchard and Woodcock, 1957), typically in the upper accumulation and lower supermicrometer range. Addressing the possibility of advection of aged aerosols from more distant sources, such as the MIZ, Heintzenberg and Leck (2012) used statistics of modal aerosol number concentrations from all four Oden-based expeditions. The scavenging of aerosol particles in fog and low clouds in low-level air entering the pack ice from the MIZ in summer is discussed. Herein, the MIZ as a sink region for particles in the submicrometer size range, within $<2$ days of travel time from the ice edge (Nilsson and Leck, 2002), was confirmed. For ASCOS in general, the cumulative probability distribution of the travel time of air over ice since its last contact with the open sea suggests that $50 \%$ of the air traveled longer than three days (Heintzenberg and Leck, 2012). The conversion time of fresh sea salt to aged sea salt, establishing itself by chloride displacement, depends, among others things, on the concentration of trace gases such as $\mathrm{N}_{2} \mathrm{O}_{5(\mathrm{~g})}, \mathrm{HNO}_{3(\mathrm{~g})}$, and $\mathrm{H}_{2} \mathrm{SO}_{4(\mathrm{~g})}$. This conversion was observed via single-particle mass spectrometry to take place in less than one day in a polluted atmosphere (Gard et al., 1998). Song and Carmichael (1999) modeled a substantial decrease in chloride levels of sea salt particles in less than $48 \mathrm{~h}$ for the Yellow Sea. However, the pollution levels from both studies cannot be applied to the atmospheric situation during ASCOS, and a detailed analysis of the chloride displacement is difficult due 
to the semi-quantitative ATOFMS data output and the deficient statistics of analyzed sea salt particles. As a consequence, quantitative relationships between the time of advection/aging times and the chloride ion intensities measured with the ATOFMS were not established.

In addition to sea salt and inorganic ECOC particles, minor fractions of metal-dominated and mineral-dust-like particles were detected (type 4 and 5, respectively). A detailed source characterization study for these small numbers of analyzed particles was not conducted as the lack of statistics made a further analysis infeasible. The particles contained in both classes did not occur during a confined time period but were instead distributed over the entire IF measurement period. As a consequence, a source was not apportioned to type 4 and 5 particles. The metal-containing particles showed distinct traces of $\mathrm{Li}, \mathrm{Pb}, \mathrm{Ba}, \mathrm{V}, \mathrm{Mo}, \mathrm{Ag}$, and $\mathrm{Al}$ in various combinations. In general, particles with dominant metal peaks are an indication of fuel combustion (e.g., V as a marker for ship emissions), industrial emissions, particles from incinerators, fly ash, or mineral dusts (e.g., Moffet et al., 2008; Spencer et al., 2008; Qin et al., 2012; Dall'Osto et al., 2013). The more dust-like compositions including traces of ${ }^{40} \mathrm{Ca}^{+}$, ${ }^{28} \mathrm{Si}^{+},{ }^{27} \mathrm{Al}^{+}$, and their oxides clearly separate particles of type 4 from those of type 5. Since some of the mineral-dustlike particles show distinct ion peaks at ${ }^{26} \mathrm{CN}^{-},{ }^{42} \mathrm{CNO}^{-}$, and/or contained phosphate (see example in the Supplement), an assignment to soil dust particles is plausible. The occurrence of peaks assigned to metal compounds in the $E C O C$ $K$-sulfate metals type $1 \mathrm{~d}$ are either a consequence of coagulation processes between particles of type $1 \mathrm{a}$ and $1 \mathrm{~b}$ at the time of combustion with metal-containing particles (e.g., such as type 4) or are related to primary, metal-containing sources of the particles. Particles of type 3 will be discussed in Sect. 3.3.

Besides those from ASCOS and the previous Oden-based expeditions, no chemical composition measurements of the summertime Arctic aerosol exist from a location as remote as the ice floe station. Information on the particles' composition is restricted to aerosols collected at different locations and south of $82^{\circ} \mathrm{N}$, and thus its comparability to the ASCOS data set is very limited. The only mass-spectrometric data stem from a ground-based study carried out at the Polar Environment Atmospheric Research laboratory (PEARL; $80^{\circ} \mathrm{N}, 86^{\circ} \mathrm{W} ; 610 \mathrm{~m}$ a.s.l. in the free troposphere) in summer 2006 (Kuhn et al., 2010). Another publication by Quinn et al. (2007) reports on long-term measurements of the Arctic aerosol and uses data from several Arctic research sites (63 to $82^{\circ} \mathrm{N}$ ) and of all seasons of the year (1980s to 2004). Both studies have in common that particles of anthropogenic origin and/or biomass burning were observed in the Arctic boundary layer during summertime conditions. However, forest fires had much less impact on the Arctic surface sites in summertime than in winter or spring (Quinn et al., 2007). Our observations are consistent with both of these studies in that we have observed elevated biomass burning/biofuel particle numbers at a remote Arctic location outside of the
"Arctic haze" period. Furthermore, their findings help explain the presence of residual particles from biomass burning/biofuel plumes at very low concentrations throughout the entire ATOFMS measurement period of ASCOS.

\subsubsection{Marginal ice station}

The dominant particle type detected at the MIZ station was the ECOC-K-sulfate-CN type (1b) with a fraction of $53 \%$ from all particles analyzed in the size range covered by the ATOFMS. Here, the sum of the fractions of all inorganic ECOC types (1a-1d) is $55 \%$. Excluding the inorganic carbonaceous aerosol types, sea salt particles made up a fraction of approximately $38 \%$. Almost $80 \%$ of all the sea salt particles contained nitrates and sulfates of the form that indicates atmospheric aging of the particles prior to reaching the ship. Only a fraction (less than $3 \%$ ) of all particles showed a signature of "fresh" or "pure" sea salt. Less than $1 \%$ of the particles were metal containing, and about $6 \%$ remained unidentified.

\subsubsection{Open water station}

At the open water station, the total number of particles analyzed was only 85 during the $12 \mathrm{~h}$ measurement period. Here, the dominant particle type was the ECOC-K-sulfate-metals type $1 \mathrm{~d}$ with metal ions representing $\mathrm{V}, \mathrm{Ba}$, and Mo. The sum of the fractions of all inorganic carbonaceous types was more than $80 \%$. The combination of metal ions like $\mathrm{V}$ with inorganic components, mainly sulfate and EC/OC fragments, is typically found in particles stemming from fossil fuel combustion. Ship exhaust is a possible source for these particles (Ault et al., 2009, 2010). The presence of Ba could point to incineration and refuse burning (Moffet et al., 2008). Mo was observed via ATOFMS in individual particles from automobile emissions (Silva et al., 1999). In nature, Mo can be found in various oxidation states in minerals as well as in enzymes of living organisms. The combination of the trace elements observed while at the OW station suggest diverse particle sources of anthropogenic origin. The particles arrived at the ship internally mixed, suggesting a coagulation of the particles at the location of combustion. The fraction of sea salt particles was relatively low compared to the two other stations. As the generation rate of sea salt aerosol has a shown positive wind speed dependence (Lewis and Schwartz, 2004; de Leeuw et al., 2011), this finding is consistent with a lower wind speed of $2 \mathrm{~m} \mathrm{~s}^{-1}$ averaged over the $12 \mathrm{~h}$ measurement period for the OW station compared to $6 \mathrm{~m} \mathrm{~s}^{-1}$ averaged over $24 \mathrm{~h}$ for the MIZ station. The sea salt particles were either mixed or aged, again suggesting an aged marine air mass encountered while at the OW station. 


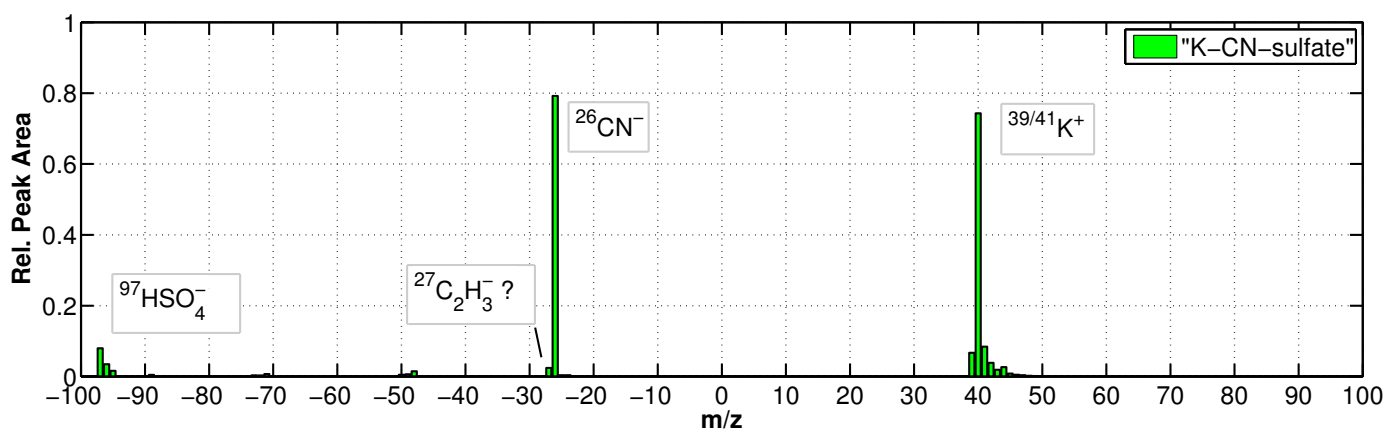

Figure 8. Mass spectra of particle type 3, $\mathrm{K}$-CN-sulfate. This particle type represents a possible candidate for an ocean-derived, biological aerosol. Note that due to a software feature the peak at $m / z+40$ actually belongs to ${ }^{39} \mathrm{~K}^{+}$(please refer to the text for a more detailed explanation).

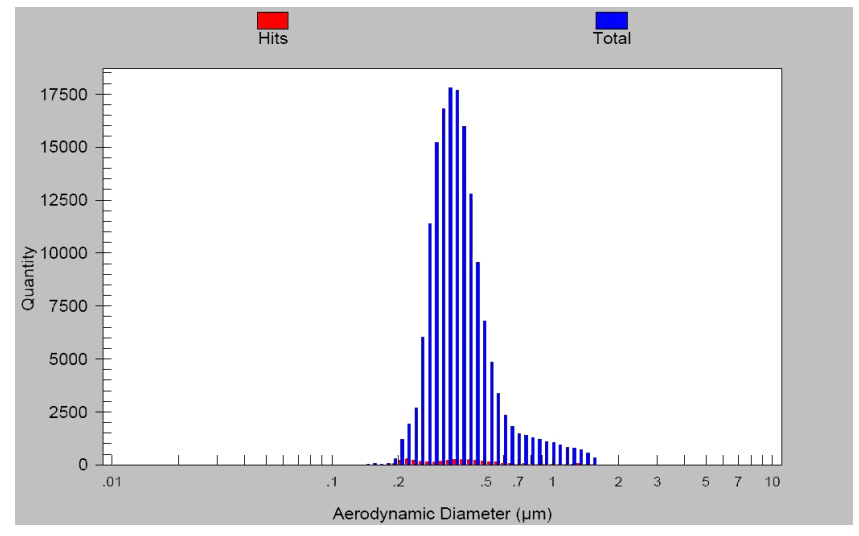

Figure 9. ATOFMS-measured aerodynamic size distribution of particles that were "sized" (blue bars) and subsequently "hit" (red bars) by the ionization laser, i.e., particles that produced a mass spectrum and were chemically analyzed. All particles measured at the IF station are combined.

\section{3 $\mathrm{K}$-CN-sulfate type particles - proxies of ocean-derived biological particles?}

As outlined in the Introduction, the abundance and chemical properties of ocean-derived particles of biogenic origin (polymer gels), as well as their potential to act as $\mathrm{CCN}$ and/or IN, were some of the main research topics of the ASCOS project. The identification of a unique particle type in the marine environment by Gaston et al. (2011) during periods of elevated DMS and/or phytoplankton biomass revealed the interaction of ocean chemistry and the marine atmosphere based on single-particle mass spectrometry data. This particle type was found during several field campaigns to be enriched in organic carbon with additional intense peaks representing ${ }^{24} \mathrm{Mg}^{+},{ }^{39} \mathrm{~K}^{+}$, and ${ }^{40} \mathrm{Ca}^{+}$. Dall'Osto et al. (2005) report on a similar finding from the North Atlantic Marine Boundary Layer Experiment (NAMBLEX) where marine, $\mathrm{Mg}^{2+}$-rich particles detected via ATOFMS correlated with high organic mass concentrations detected via AMS. As sources of Mg-rich particles, viruses, bacteria, cell debris, organics released from lysed cells, or marine polymer gels are suggested. These polymer gels are polysaccharide molecules interbridged with divalent ions $\left(\mathrm{Ca}^{2+}, \mathrm{Mg}^{2+}\right)$, to which other organic compounds, such as proteins and lipids, are readily bound (Verdugo, 2012, gives a review). Also, a most recent study on laboratory-generated, "realistic" sea spray aerosol reports on ATOFMS-detected, primary biological-containing particles with fractions possibly linked to microgel formation (Prather et al., 2013). The in situ detection of primary, oceanderived particles in a bioactive marine atmosphere as presented in Gaston et al. (2011) supports the findings of Orellana et al. (2011), Leck and Bigg (2005a), and Leck et al. (2013), who observed polymer gels in atmospheric samples and cloud water collected over the high-Arctic pack ice area.

When using the ATOFMS or similar LDI-based massspectrometric techniques, ion peaks of potassium, sodium, calcium, organic fragments, nitrate (a combination of both is often reflected in peaks at ${ }^{26} \mathrm{CN}^{-}$and ${ }^{42} \mathrm{CNO}^{-}$), and phosphate are typically used as tracers for airborne continental/marine biological material such as bacteria, fungal spores, or pollen. As a large fraction of these elements can also be found in mineral dust (e.g., Gallavardin et al., 2008) the absence of dust markers such as silicon, aluminum, and iron is used to distinguish between both (Pratt et al., 2009; Pratt and Prather, 2010; Cahill et al., 2012; Cziczo et al., 2013). $\mathrm{Ca}, \mathrm{K}, \mathrm{Na}$, and $\mathrm{N}$ are well known to be essential elements for living cells, and phosphates occur in endospore nucleic acids, adenosine di- and triphosphates, and cell membranes, as shown by Fergenson et al. (2004). Nevertheless, the clear identification of airborne biological material by the ATOFMS is still a challenge due to spectral similarities to other, non-biological particle types (Cziczo et al., 2013; Pratt et al., 2009; Creamean et al., 2013). Other single-particle mass-spectrometric methods can in that sense be more specific due to the application of different or modified ionization methods (e.g., Fergenson et al., 2004; Frank et al., 
2011; Kleefsman et al., 2007). These methods show, however, consistent signatures in the elemental composition with the ATOFMS.

The ATOFMS data collected during the ASCOS cruise were screened for particle candidates of biological origin. Based on the ENCHILADA results, only two clusters (a total of 36 particles) were detected during the IF station which show slight similarities to the above-described massspectrometric features. The most prominent cluster of the observed $\mathrm{K}$ - $\mathrm{CN}$-sulfate type is shown in Fig. 8 and depicts an intense and single peak of ${ }^{39} \mathrm{~K}^{+}$in the positive mode and a dominant ${ }^{26} \mathrm{CN}^{-}$peak in the negative mode (see clustertype description above). A sulfate peak of smaller intensity can be found in the negative mode as well. The second cluster (not shown) has indications of carbonaceous material.

In accordance with the findings of Orellana et al. (2011) and Leck et al. (2013) and the unique sea spray particle type observed via ATOFMS (Gaston et al., 2011), we would expect to detect $\mathrm{Mg}$ - and/or Ca- and/or K-rich particles characterizing the local aerosol sources in the Arctic pack ice region. In the pack ice, the particles of interest, i.e., the abovementioned polymer gels, are assumed to stem from organic material in the surface microlayer of open leads and to be released into the atmosphere due to bubble bursting. Our chemical results, however, are ambiguous in this regard since ${ }^{39} \mathrm{~K}^{+}$is clearly present in the particle type presented here but the most specific peak ${ }^{23} \mathrm{Mg}^{+}$is absent. Instead, a high intensity of ${ }^{26} \mathrm{CN}^{-}$is evident, which was not observed by neither Gaston et al. (2011) nor by Dall'Osto et al. (2005) but was named as an indicator of biological aerosols in other studies (Fergenson et al., 2004; Pratt et al., 2009; Creamean et al., 2013). Pronounced ion peaks at ${ }^{26} \mathrm{CN}^{-}$and ${ }^{42} \mathrm{CNO}^{-}$have also been found in particle type $1 \mathrm{~b}$, which could indicate an internal mixing of the inorganic carbonaceous and biological particles.

It has to be noted that for this cluster type the intensity of the $\mathrm{K}^{+}$cation current was extremely high, and thus the signal from it routinely saturated the detector and/or the dynamic range of the data acquisition system. As a consequence, the peak area extends over the unit mass resolution of the mass spectra. When using ENCHILADA, the enlarged peak area resulted in an attribution of the ${ }^{39} \mathrm{~K}^{+}$ion peak to an $m / z$ value of +40 , as seen in Fig. 8. As a further consequence, the presence of low-intensity ${ }^{40} \mathrm{Ca}^{+}$ions as an additional signature for the sea spray particles could be masked.

Based on the biogenic particle sizes, the prerequisite for detection of those by means of ATOFMS should have been given. Leck et al. (2013) report that marine biogenic polysaccharide-containing polymer gels were detected on filter samples in all particle sizes ranging from 0.035 to $10 \mu \mathrm{m}$ in diameter collected during the 2008 ASCOS campaign. For the entire cruise, approximately $60 \mathrm{wt} \%$ of the polysaccharides were found in the submicrometer and $40 \%$ in the supermicrometer range. During the IF period, on average $53 \pm 24 \%$ of the detected polysaccharides were apportioned in the Aitken and accumulation mode. Based on these findings, the size range of the biogenic particulate matter and that of the ATOFMS should have overlapped to some extent, but the peak polysaccharide mass in the Aitken - and small accumulation modes for long advection times over the pack ice - could not be seen by the ATOFMS. The differences of the $\mathrm{K}$-CN-sulfate type from the other four types indicate a different source which could be of marine biogenic origin. In general, taking the overall lack of single-particle massspectrometric reference data from this measurement location of ASCOS into consideration, the mass-spectrometric tracers for ocean-derived biological particles as reported in the literature do not necessarily have to be universal. However, the similarities in biogenic marker ions compared to literature data are limited, as indicated by the lack of $\mathrm{Mg}^{2+}, \mathrm{Na}^{+}$, phosphate, oftentimes transition metals (Prather et al., 2013), and less intense organic ions as, for example, observed by Gaston et al. (2011). Also, as outlined in the Supplement, the temporal trend of the $\mathrm{K}$ - $\mathrm{CN}$-sulfate type particles shows similarities with those of the type 1 particles (note that the temporal trend analysis is only based on 36 particles). Altogether, these findings make assignment of these clusters to a biogenic, ocean-derived primary particle source rather unlikely and prevented us from clear source apportionment of this particle type.

Finally, we investigated the temporal trend of type 3 particles in the context of particle nucleation as, for example, observed by Dall'Osto et al. (2012) for marine aerosol: the occurrence of type 3 particles did not coincide with the only nucleation event observed on 2 September (not shown; for details on the event please refer to Karl et al. $(2012,2013)$ ). This finding excludes the freshly nucleated particles from being a direct source of the $\mathrm{K}$ - $\mathrm{CN}$-sulfate type. However, nucleation-mode particles cannot be seen by the ATOFMS due to their small size. Thus, only sufficiently large particles can be detected and indirectly linked to particle nucleation events after particle growth over a certain time span.

\subsection{ATOFMS particle detection during ASCOS}

As mentioned earlier, the hit rate of the ATOFMS when measuring ambient particles was exceptionally low. Although an unfavorable outcome, this aspect is still of interest for data interpretation. This is due to the fact that the hit rate was found in a typical range when the instruments' aerodynamic lens and lasers were aligned and optimized during size and mass calibration measurements performed during the campaign.

The low ATOFMS hit rate during ASCOS is demonstrated in Fig. 9. Herein, the aerodynamic size distribution of sized and hit particles merged for the entire IF period is presented. The hit rate was on average $<1 \%$ for the entire cruise, with decreasing hit rates from the OW to the IF station. Typically, hit rates of the ATOFMS are on the order of 10 to several tens of percent in the size range below $1 \mu \mathrm{m}$. Thus, the low hit rate might give us an indication of the properties of the 
missed fraction of particles; known factors to reduce the hit rate of the ATOFMS are (i) particles composed of material that does not absorb the $266 \mathrm{~nm}$ radiation of the ionization laser (e.g., pure ammonium sulfate particles; Spencer et al., 2008; Wenzel et al., 2003); (ii) particles that still contain water as wet particles divert the energy that would go to ionizing the molecules into evaporating the water, thus suppressing ionization; (iii) particles whose flight path is affected by their shape and/or morphology such that the calculated "hit position" for the ionization laser deviates from the actual one; and (iv) charged particles that deviate from the ATOFMS source region due to the voltages applied at the source plates (Shields, 2008).

Unfortunately, the reason for the low hit rates observed during ASCOS cannot be clearly attributed to one of the above mentioned factors. General instrumental problems cannot be ruled out completely, although the instrument hit rates observed during the regular ATOFMS mass and sizecalibration measurements were in the expected range of operation. As the relative humidity $(\mathrm{RH})$ was not measured directly upstream of the ATOFMS inlet, and no additional, active drying of the ATOFMS sample flow was performed, the possibility that the particles still contained water is given as well. Although the RH was assumed to be $<30 \%$ at the exit of the inlet system as noted above, the short residence time of the particles within the flow system of approximately $4-5 \mathrm{~s}$ might have been insufficient for complete efflorescence. The mass spectra did not contain a signal at $\mathrm{m} / z+19\left(\mathrm{H}_{3} \mathrm{O}^{+}\right)$, which is an indication of the absence of wet particles. Another indicator of wet particles is the deficiency of negative ion spectra (Neubauer et al., 1997, 1998), which has only been observed on occasion $(<2 \%$ at IF). No neutralizer to minimize charge effects was employed upstream of the ATOFMS's inlet during the ambient measurements. Consequently, a combination of particle losses due to charge effects and a chemical bias are the most prominent factors to take into consideration herein. In terms of a chemical bias, one could speculate that particles of biological origin as proposed by Leck and Bigg (2005a) and ATOFMS measured by Gaston et al. (2011) make up the fraction of sized but nonchemically analyzed particles since they are partly composed of mono/polysaccharides. We do not expect pure sugars to absorb well as their monosaccharide subunits do not have any aromaticity (which is usually required for organic chemicals to absorb at $266 \mathrm{~nm}$ ). Also, Gaston et al. (2011) observed the ATOFMS hit rate plummeted in bioactive marine regions where the discussed $\mathrm{Mg}$-type particles were present. This finding supports the idea of a chemical bias. However, as we have no information on the $266 \mathrm{~nm}$ absorbance properties of the marine gel particles, but ocean-derived particles from a potentially similar gel source as discussed herein were detected by Gaston et al. (2011) using an ATOFMS, no clear conclusion from the low hit rate can be drawn.

\section{Conclusions}

Data are presented from the ASCOS field campaign carried out on the icebreaker Oden in the high-Arctic pack ice area north of $80^{\circ}$ through the seasonal transition from sea-ice melt to freeze-up in summer 2008. The chemical composition of individual aerosol particles in the size range between approximately $200 \mathrm{~nm}$ and $3 \mu \mathrm{m}$ in diameter was measured in the marine boundary layer with a single-particle mass spectrometer at three different stations: at an open water station, at a marginal ice station, and at an ice floe station in the pack ice region. In that size range, the dominant fraction of the ATOFMS-detected aerosol showed a common elemental and organic carbon pattern along with pronounced ion traces of potassium and sulfate that indicate the presence of particles originating from biomass or biofuel burning. The inorganic carbonaceous particles were internally mixed with oxidized organics and partly with metals, which suggests longdistance transport of the particles from lower latitudes into the high Arctic. The majority of these particles most likely stem from continental sources undergoing atmospheric aging and mixing on their way into the Arctic. At the ice floe station, the highest frequency of detection of this particle type occurred during a meteorological period of a cloud-driven mixed layer in the upper part of the boundary layer coupled to the mixed layer at the surface that allowed upper-level aerosol particles to reach the surface. Trajectory analysis of this period (Shupe et al., 2013; Leck et al., 2013) suggests that the air in the upper boundary layer had come from the Canadian archipelago whereas that in the lowest $100 \mathrm{~m}$ had been over the ice for at least 10 days. Several studies from ASCOS support this finding and indicate the presence of continental-sourced air in the boundary layer during the same time period (Paatero et al., 2009; Chang et al., 2011; Leck et al., 2013; Kupiszewski et al., 2013). However, particles of the biomass/biofuel burning type were also observed outside the above-described period, suggesting that residuals of such continental air represent a fraction of the aerosol detected by the ATOFMS at the location of the ship, with its significance still to be determined. Sea salt particles made up the second largest fraction of classified particles with variable contributions at the three different measurement locations. Certain tracer compounds found in the sea salt particles support the interpretation of atmospherically aged particles. A comparison to mass-spectrometric data of the bulk aerosol measured using an aerosol mass spectrometer (AMS) revealed somewhat contrasting results. Chang et al. (2011) observed a large mass fraction of $31 \%$ attributed almost purely to organic, which was not observed by the ATOFMS. However, Chang et al.(2011) also report on a continental factor deduced from their source-apportionment study that correlates in time with the inorganic carbonaceous particle type measured by the ATOFMS (note that the AMS and ATOFMS have different particle size ranges, with the AMS starting at $100 \mathrm{~nm}$ in diameter aerodynamic size). 
An interesting feature observed in the ASCOS data set concerns the low number of analyzed particles. The socalled "hit rate" of the ATOFMS, i.e., the percentage of particles (per time interval) that were hit by the ionization laser, desorbed its energy and produced a mass spectrum that was exceptionally low during the entire cruise. Only $\sim 1 \%$ of the particles sized by the ATOFMS could be chemically analyzed. This can be attributed to instrumental features or insufficiently dried (i.e., wet) particles whose water fraction diverts the laser energy when hit. A chemical bias, however, is also possible due to particles mainly consisting of material transparent at the $266 \mathrm{~nm}$ wavelength of the desorption/ionization laser. Acting on the latter assumption, one could hypothesize that these non-ionized, "missing" particles represent ocean-derived primary organic aerosols from the ocean-surface microlayer as observed by Leck and Bigg (2005a), Bigg and Leck (2008), Orellana et al. (2011), andLeck et al. (2013) and potentially detected via ATOFMS by Dall'Osto et al. (2005) and Gaston et al. (2011). Monosaccharides as major building blocks of polymer gels, one of those ocean-derived material types that have been found in the Arctic atmosphere, would fulfill the requirement of being scarcely ionized by the ATOFMS. These particles, however, do not necessarily consist of pure saccharides as they readily bond proteins and lipids (Facchini et al., 2008; Hawkins and Russell, 2010; Leck and Bigg, 2005a) when ejected into the atmosphere from the ocean-surface microlayer by bubble bursting. In this study, only a small fraction of particles, less than $2 \%$ analyzed from the ice floe station, showed a massspectrometric pattern that potentially indicates a biological source.

In general, only a minor fraction of the total aerosol could be sampled by the ATOFMS. In 2008, the dominant number of aerosols were found in the nucleation and accumulation mode, which seems to be a fundamental feature of the high-Arctic summer aerosol (Heintzenberg and Leck, 2012). As a consequence, the information gathered on individual aerosols was limited by the particle size range covered by the ATOFMS. Due to the overall low number of particles that produced a mass spectrum, a robust statistical analysis of the ATOFMS data was restricted. Hence, it is questionable how representative our data are for the summertime high-Arctic aerosol. In addition to measurement statistics, this also concerns more general aspects like the representativeness of an aerosol sampled at the ship at a certain location and at a certain time compared to the aerosol present at higher altitudes, and the spatial and temporal occurrence of long-range-transported air introducing aerosol particles from continental sources into the marine boundary layer compared to advection of air over the pack ice. During ASCOS, pollution or biomass burning plumes, which we did see aloft in the free troposphere on occasion (Kupiszewski et al., 2013), was/were detected at the ship only once: about a few days out of the 7 weeks of the expedition indicate a continental source within the boundary layer. In order to gain more knowledge on such occasions so as to assess their importance for aerosol-cloud interactions in the Arctic in comparison to local biogenic primary aerosol sources or advected aerosols from the marginal ice zone or open sea south thereof - as well as how they influence the chemical composition, the mixing state, the sources and the abundances of the highArctic aerosol - more comprehensive in situ data have to be collected north of $80^{\circ}$.

\section{The Supplement related to this article is available online at doi:10.5194/acp-14-7409-2014-supplement.}

Acknowledgements. This work is part of ASCOS (the Arctic Summer Cloud Ocean Study) and was funded by ETH grants. ASCOS was made possible by funding from the Knut and Alice Wallenberg Foundation and the DAMOCLES European Union 6th Framework Programme Integrated Research Project. The Swedish Polar Research Secretariat (SPRS) provided access to the icebreaker Oden and logistical support. We are grateful to the chief scientists, Caroline Leck and Michael Tjernström, for planning and coordination of ASCOS; to the SPRS logistical staff; and to the Oden's captain, Mattias Peterson, and his crew. ASCOS is an IPY project under the umbrella of AICIA-IPY and an endorsed SOLAS project. The authors would like to thank B. Brooks and J. Heintzenberg for providing data, and A. Stohl and J. Burkhart for the provision of the FLEXPART model. The latter were supported by the Norwegian Research Council as part of the CLIMSLIP project.

Edited by: G. de Leeuw

\section{References}

Ault, A. P., Moore, M. J., Furutani, H., and Prather, K. A.: Impact of emissions from the Los Angeles port region on San Diego air quality during regional transport events, Environ. Sci. Technol., 43, 3500-3506, doi:10.1021/es8018918, 2009.

Ault, A. P., Gaston, C. J., Wang, Y., Dominguez, G., Thiemens, M. H., and Prather, K. A.: Characterization of the single particle mixing state of individual ship plume events measured at the port of Los Angeles, Environ. Sci. Technol., 44, 1954-1961, doi:10.1021/es902985h, 2010.

Bhave, P. V., Allen, J. O., Morrical, B. D., Fergenson, D. P., Cass, G. R., and Prather, K. A.: A field-based approach for determining atofms instrument sensitivities to ammonium and nitrate, Environ. Sci. Technol., 36, 4868-4879, doi:10.1021/es015823i, 2002.

Bigg, E. K.: Ice forming nuclei in the high Arctic, Tellus B, 48, 223-233, doi:10.1034/j.1600-0889.1996.t01-1-00007.x, 1996.

Bigg, E. K. and Leck, C.: The composition of fragments of bubbles bursting at the ocean surface, J. Geophys. Res., 113, D11209, doi:10.1029/2007JD009078, 2008.

Bigg, E. K., Leck, C., and Tranvik, L.: Particulates of the surface microlayer of open water in the central Arctic Ocean in summer, 
Mar. Chem., 91, 131-141, doi:10.1016/j.marchem.2004.06.005, 2004.

Blanchard, D. C. and Woodcock, A. H.: Bubble formation and modification in the sea and its meterological significance, Tellus, 9, 145-148, 1957.

Brock, C. A., Cozic, J., Bahreini, R., Froyd, K. D., Middlebrook, A. M., McComiskey, A., Brioude, J., Cooper, O. R., Stohl, A., Aikin, K. C., de Gouw, J. A., Fahey, D. W., Ferrare, R. A., Gao, R.-S., Gore, W., Holloway, J. S., Hübler, G., Jefferson, A., Lack, D. A., Lance, S., Moore, R. H., Murphy, D. M., Nenes, A., Novelli, P. C., Nowak, J. B., Ogren, J. A., Peischl, J., Pierce, R. B., Pilewskie, P., Quinn, P. K., Ryerson, T. B., Schmidt, K. S., Schwarz, J. P., Sodemann, H., Spackman, J. R., Stark, H., Thomson, D. S., Thornberry, T., Veres, P., Watts, L. A., Warneke, C., and Wollny, A. G.: Characteristics, sources, and transport of aerosols measured in spring 2008 during the aerosol, radiation, and cloud processes affecting Arctic Climate (ARCPAC) Project, Atmos. Chem. Phys., 11, 24232453, doi:10.5194/acp-11-2423-2011, 2011.

Brooks, B., Smith, M., Hill, M., and O’Dowd, C.: Sizedifferentiated volatility analysis of internally mixed laboratory-generated aerosol, J. Aerosol Sci., 33, 555-579, doi:10.1016/S0021-8502(01)00192-6, 2002.

Brooks, B. J., McQuaid, J. B., Smith, M. H., Crosier, J., Williams, P. I., Coe, H., and Osborne, S.: Intercomparison of VACC- and AMS-derived nitrate, sulphate and ammonium aerosol loadings during ADRIEX, Q. J. Roy. Meteor. Soc., 133, 77-84, doi:10.1002/qj.90, 2007.

Cahill, J. F., Suski, K., Seinfeld, J. H., Zaveri, R. A., and Prather, K. A.: The mixing state of carbonaceous aerosol particles in northern and southern California measured during CARES and CalNex 2010, Atmos. Chem. Phys., 12, 1098911002, doi:10.5194/acp-12-10989-2012, 2012.

Chang, R. Y.-W., Leck, C., Graus, M., Müller, M., Paatero, J., Burkhart, J. F., Stohl, A., Orr, L. H., Hayden, K., Li, S.M., Hansel, A., Tjernström, M., Leaitch, W. R., and Abbatt, J. P. D.: Aerosol composition and sources in the central Arctic Ocean during ASCOS, Atmos. Chem. Phys., 11, 1061910636, doi:10.5194/acp-11-10619-2011, 2011.

Covert, D. S., Wiedensohler, A., Aalto, P., Heintzenberg, J., McMurry, P., and Leck, C.: Aerosol number size distributions from 3 to $500 \mathrm{~nm}$ diameter in the arctic marine boundary layer during summer and autumn, Tellus B, 48, 197-212, doi:10.1034/j.16000889.1996.t01-1-00005.x, 1996.

Creamean, J. M., Suski, K. J., Rosenfeld, D., Cazorla, A., DeMott, P. J., Sullivan, R. C., White, A. B., Ralph, F. M., Minnis, P., Comstock, J. M., Tomlinson, J. M., and Prather, K. A.: Dust and biological aerosols from the Sahara and Asia influence precipitation in the Western US, Science, 339, 1572-1578, doi:10.1126/science.1227279, 2013.

Curry, J. A. and Ebert, E. E.: Annual cycle of radiation fluxes over the arctic ocean: sensitivity to cloud optical properties, J. Climate, 5, 1267-1280, doi:10.1175/15200442(1992)005<1267:ACORFO>2.0.CO;2, 1992.

Curry, J. A., Hobbs, P. V., King, M. D., Randall, D. A., Minnis, P., Isaac, G. A., Pinto, J. O., Uttal, T., Bucholtz, A., Cripe, D. G., Gerber, H., Fairall, C. W., Garrett, T. J., Hudson, J., Intrieri, J. M., Jakob, C., Jensen, T., Lawson, P., Marcotte, D., Nguyen, L., Pilewskie, P., Rangno, A.,
Rogers, D. C., Strawbridge, K. B., Valero, F. P. J., Williams, A. G., and Wylie, D.: FIRE arctic clouds experiment, B. Am. Meteorol. Soc., 81, 5-29, doi:10.1175/15200477(2000)081<0005:FACE>2.3.CO;2, 2000.

Cziczo, D. J., Froyd, K. D., Hoose, C., Jensen, E. J., Diao, M., Zondlo, M. A., Smith, J. B., Twohy, C. H., and Murphy, D. M.: Clarifying the dominant sources and mechanisms of cirrus cloud formation, Science, 340, 1320-1324, doi:10.1126/science.1234145, 2013.

Dall'Osto, M. and Harrison, R. M.: Urban organic aerosols measured by single particle mass spectrometry in the megacity of London, Atmos. Chem. Phys., 12, 4127-4142, doi:10.5194/acp12-4127-2012, 2012.

Dall'Osto, M., Ceburnis, D., Monahan, C., Worsnop, D. R., Bialek, J., Kulmala, M., Kurten, T., Ehn, M., Wenger, J., Sodeau, J., Healy, R., and O'Dowd, C.: Nitrogenated and aliphatic organic vapors as possible drivers for marine secondary organic aerosol growth, J. Geophys. Res., 117, D12, doi:10.1029/2012JD017522, 2012.

Dall'Osto, M., Beddows, D. C. S., Kinnersley, R. P., Harrison, R. M., Donovan, R. J., and Heal, M. R.: Characterization of individual airborne particles by using aerosol time-of-flight mass spectrometry at Mace Head, Ireland, J. Geophys. Res., 109, D21302, doi:10.1029/2004JD004747, 2004.

Dall'Osto, M., Harrison, R. M., Furutani, H., Prather, K. A., Coe, H., and Allan, J. D.: Studies of aerosol at a coastal site using two aerosol mass spectrometry instruments and identification of biogenic particle types, Atmos. Chem. Phys. Discuss., 5, 1079910838, doi:10.5194/acpd-5-10799-2005, 2005.

Dall'Osto, M., Ovadnevaite, J., Ceburnis, D., Martin, D., Healy, R. M., O'Connor, I. P., Kourtchev, I., Sodeau, J. R., Wenger, J. C., and O'Dowd, C.: Characterization of urban aerosol in Cork city (Ireland) using aerosol mass spectrometry, Atmos. Chem. Phys., 13, 4997-5015, doi:10.5194/acp-13-49972013, 2013.

Decho, A. W.: Microbial exopolymer secretions in ocean environments: their role(s) in food webs and marine processes, Oceanogr. Mar. Biol., 28, 73-153, 1990.

de Leeuw, G., Andreas, E. L., Anguelova, M. D., Fairall, C. W., Lewis, E. R., O'Dowd, C., Schulz, M., and Schwartz, S. E.: Production flux of sea spray aerosol, Rev. Geophys., 49, RG2001, doi:10.1029/2010RG000349, 2011.

Draxler, R. and Rolph, G.: HYSPLIT (HYbrid Single-Particle Lagrangian Integrated Trajectory), Tech. rep., NOAA Air Resour. Lab, available at: http://ready.arl.noaa.gov/HYSPLIT.php (last access: 7 April 2010), 2011.

Facchini, M. C., Rinaldi, M., Decesari, S., Carbone, C., Finessi, E., Mircea, M., Fuzzi, S., Ceburnis, D., Flanagan, R., Nilsson, E. D., de Leeuw, G., Martino, M., Woeltjen, J., and O'Dowd, C. D.: Primary submicron marine aerosol dominated by insoluble organic colloids and aggregates, Geophys. Res. Lett., 35, L17814, doi:10.1029/2008GL034210, 2008.

Fergenson, D. P., Pitesky, M. E., Tobias, H. J., Steele, P. T., Czerwieniec, G. A., Russell, S. C., Lebrilla, C. B., Horn, J. M., Coffee, K. R., Srivastava, A., Pillai, S. P., Shih, M.-T. P., Hall, H. L., Ramponi, A. J., Chang, J. T., Langlois, R. G., Estacio, P. L., Hadley, R. T., Frank, M., and Gard, E. E.: Reagentless detection and classification of individual bioaerosol particles in seconds, Anal. Chem., 76, 373-378, doi:10.1021/ac034467e, 2004. 
Frank, M., Gard, E. E., Tobias, H. J., Adams, K. L., Bogan, M. J., Coffee, K. R., Farquar, G. R., Fergenson, D. P., Martin, S. I., Pitesky, M., Riot, V. J., Srivastava, A., Steele, P. T., and Williams, A. M.: Single-Particle Aerosol Mass Spectrometry (SPAMS) for high-throughput and rapid analysis of biological aerosols and single cells, in: Rapid Characterization of Microorganisms by Mass Spectrometry, Am. Chem. Soc., 161-196, doi:10.1021/bk-2011-1065.ch010, 2011.

Friedman, B., Herich, H., Kammermann, L., Gross, D. S., Arneth, A., Holst, T., and Cziczo, D. J.: Subarctic atmospheric aerosol composition: 1. Ambient aerosol characterization, J. Geophys. Res., 114, D13203, doi:10.1029/2009JD011772, 2009.

Gallavardin, S., Lohmann, U., and Cziczo, D.: Analysis and differentiation of mineral dust by single particle laser mass spectrometry, Int. J. Mass. Spectrom., 274, 56-63, doi:10.1016/j.ijms.2008.04.031, 2008.

Gard, E., Mayer, J. E., Morrical, B. D., Dienes, T., Fergenson, D. P., and Prather, K. A.: Real-time analysis of individual atmospheric aerosol particles: design and performance of a portable ATOFMS, Anal. Chem., 69, 4083-4091, doi:10.1021/ac970540n, 1997.

Gard, E. E., Kleeman, M. J., Gross, D. S., Hughes, L. S., Allen, J. O., Morrical, B. D., Fergenson, D. P., Dienes, T., Gälli, M. E., Johnson, R. J., Cass, G. R., and Prather, K. A.: Direct observation of heterogeneous chemistry in the atmosphere, Science, 279, 1184 -1187, doi:10.1126/science.279.5354.1184, 1998.

Gaston, C. J., Furutani, H., Guazzotti, S. A., Coffee, K. R., Bates, T. S., Quinn, P. K., Aluwihare, L. I., Mitchell, B. G., and Prather, K. A.: Unique ocean-derived particles serve as a proxy for changes in ocean chemistry, J. Geophys. Res., 116, D18310, doi:10.1029/2010JD015289, 2011.

Gaudichet, A., Echalar, F., Chatenet, B., Quisefit, J. P., Malingre, G., Cachier, H., Buat-Menard, P., Artaxo, P., and Maenhaut, W.: Trace elements in tropical African savanna biomass burning aerosols, J. Atmos. Chem., 22, 19-39, doi:10.1007/BF00708179, 1995.

Ge, Z., Wexler, A. S., and Johnston, M. V.: Laser desorption/ionization of single ultrafine multicomponent aerosols, Environ. Sci. Technol., 32, 3218-3223, doi:10.1021/es980104y, 1998.

Gross, D.: Environmental chemistry through intelligent atmospheric data analysis, Environ. Modell. Softw., 69, 4083-4091, doi:10.1021/ac970540n, 2011.

Gross, D. S., Galli, M. E., Silva, P. J., Wood, S. H., Liu, D.-Y., and Prather, K. A.: Single particle characterization of automobile and diesel truck emissions in the Caldecott Tunnel, Aerosol Sci. Tech., 32, 152-163, doi:10.1080/027868200303858, 2000.

Harrison, R. M., Msibi, M. I., Kitto, A. M. N., and Yamulki, S.: Atmospheric chemical transformations of nitrogen compounds measured in the north sea experiment, September 1991, Atmos. Environ., 28, 1593-1599, doi:10.1016/1352-2310(94)90305-0, 1994.

Hawkins, L. N. and Russell, L. M.: Polysaccharides, proteins, and phytoplankton fragments: four chemically distinct types of marine primary organic aerosol classified by single particle spectromicroscopy, Adv. Meteorol., 612132, doi:10.1155/2010/612132, 2010.
Heintzenberg, J.: Particle size distribution and optical properties of Arctic haze, Tellus, 32, 251-260, doi:10.1111/j.21533490.1980.tb00952.x, 1980.

Heintzenberg, J. and Leck, C.: Seasonal variation of the atmospheric aerosol near the top of the marine boundary layer over Spitsbergen related to the Arctic sulphur cycle, Tellus B, 46, 5267, doi:10.1034/j.1600-0889.1994.00005.x, 2004.

Heintzenberg, J. and Leck, C.: The summer aerosol in the central Arctic 1991-2008: did it change or not?, Atmos. Chem. Phys., 12, 3969-3983, doi:10.5194/acp-12-3969-2012, 2012.

Held, A., Brooks, I. M., Leck, C., and Tjernström, M.: On the potential contribution of open lead particle emissions to the central Arctic aerosol concentration, Atmos. Chem. Phys., 11, 30933105, doi:10.5194/acp-11-3093-2011, 2011.

Hutter, A., Larsen, R., Maring, H., and Merrill, J.: 222Rn at Bermuda and Mauna Loa: local and distant sources, J. Radioanal. Nucl. Ch., 193, 309-318, doi:10.1007/BF02039888, 1995.

Intrieri, J. M., Fairall, C. W., Shupe, M. D., Persson, P. O. G., Andreas, E. L., Guest, P. S., and Moritz, R. E.: An annual cycle of Arctic surface cloud forcing at SHEBA, J. Geophys. Res., 107, 8039, doi:10.1029/2000JC000439, 2002.

IPCC: Contribution of Working Group I to the Fourth Assessment, in: IPCC, Intergovernmental Panel on Climate Change: Climate Change 2007: The Physical Science Basis, Report of the Intergovernmental Panel on Climate Change, Cambridge University Press, Cambridge, UK, New York, NY, USA, 996 pp., 2007.

Jeffries, M. O. and Richter-Menge, J.: The Arctic, in: State of the Climate in 2012, B. Am. Meteorol. Soc., 93, S127-S147, 2012.

Kane, D. B. and Johnston, M. V.: Size and composition biases on the detection of individual ultrafine particles by aerosol mass spectrometry, Environ. Sci. Technol., 34, 4887-4893, doi:10.1021/es001323y, 2000.

Karl, M., Leck, C., Gross, A., and Pirjola, L.: A study of new particle formation in the marine boundary layer over the central Arctic Ocean using a flexible multicomponent aerosol dynamic model,Tellus B, 64, 17158, doi:10.3402/tellusb.v64i0.17158, 2012.

Karl, M., Leck, C., Coz, E., and Heintzenberg, J.: Marine nanogels as a source of atmospheric nanoparticles in the high Arctic, Geophys. Res. Lett., 40, 3738-3743, doi:10.1002/grl.50661, 2013.

Kleefsman, I., Stowers, M. A., Verheijen, P. J. T., Van Wuijckhuijse, A. L., Kientz, C. E., and Marijnissen, J. C. M.: Bioaerosol analysis by single particle mass spectrometry, Part. Part. Syst. Char., 24, 85-90, doi:10.1002/ppsc.200601049, 2007.

Kolaitis, L. N., Bruynseels, F. J., Van Grieken, R. E., and Andreae, M. O.: Determination of methanesulfonic acid and nonsea-salt sulfate in single marine aerosol particles, Environ. Sci. Technol., 23, 236-240, doi:10.1021/es00179a018, 1989.

Kuhn, T., Damoah, R., Bacak, A., and Sloan, J. J.: Characterising aerosol transport into the Canadian High Arctic using aerosol mass spectrometry and Lagrangian modelling, Atmos. Chem. Phys., 10, 10489-10502, doi:10.5194/acp-10-10489-2010, 2010.

Kupiszewski, P., Leck, C., Tjernström, M., Sjogren, S., Sedlar, J., Graus, M., Müller, M., Brooks, B., Swietlicki, E., Norris, S., and Hansel, A.: Vertical profiling of aerosol particles and trace gases over the central Arctic Ocean during summer, Atmos. Chem. Phys., 13, 12405-12431, doi:10.5194/acp-13-12405-2013, 2013.

Law, K. S. and Stohl, A.: Arctic air pollution: origins and impacts, Science, 315, 1537-1540, doi:10.1126/science.1137695, 2007. 
Leck, C. and Bigg, E. K.: Aerosol production over remote marine areas - a new route, Geophys. Res. Lett., 26, 3577-3580, doi:10.1029/1999GL010807, 1999.

Leck, C. and Bigg, E. K.: Biogenic particles in the surface microlayer and overlaying atmosphere in the central Arctic Ocean during summer, Tellus B, 57, 305-316, doi:10.1111/j.16000889.2005.00148.x, 2005a.

Leck, C. and Bigg, E. K.: Source and evolution of the marine aerosol - a new perspective, Geophys. Res. Lett., 32, L19803, doi:10.1029/2005GL023651, 2005b.

Leck, C. and Bigg, E. K.: New particle formation of marine biological origin, Aerosol Sci. Tech., 44, 570-577, doi:10.1080/02786826.2010.481222, 2010.

Leck, C. and Persson, C.: Seasonal and short-term variability in dimethyl sulfide, sulfur dioxide and biogenic sulfur and sea salt aerosol particles in the arctic marine boundary layer during summer and autumn, Tellus B, 48, 272-299, 1996.

Leck, C., Bigg, E. K., Covert, D. S., Heintzenberg, J., Maenhaut, W., Nilsson, E. D., and Wiedensohler, A.: Overview of the atmospheric research program during the International Arctic Ocean Expedition of 1991 (IAOE-91) and its scientific results, Tellus B, 48, 136-155, doi:10.1034/j.1600-0889.1996.t01-1-00002.x, 1996.

Leck, C., Nilsson, E. D., Bigg, E. K., and Backlin, L.: Atmospheric program on the Arctic Ocean Expedition 1996 (AOE-96): an overview of scientific goals, experimental approaches, and instruments, J. Geophys. Res., 106, 32051-32067, 2001.

Leck, C., Norman, M., Bigg, E. K., and Hillamo, R.: Chemical composition and sources of the high Arctic aerosol relevant for cloud formation, J. Geophys. Res., 107, 1-17, doi:10.1029/2001JD001463, 2002.

Leck, C., Tjernström, M., Matrai, P., Swietlicki, E., and Bigg, K.: Can marine micro-organisms influence melting of the Arctic pack ice?, EOS T. Am. Geophys. Un., 85, 25-32, doi:10.1029/2004EO030001, 2004.

Leck, C., Gao, Q., Mashayekhy Rad, F., and Nilsson, U.: Size resolved airborne particulate polysaccharides in summer high Arctic, Atmos. Chem. Phys. Discuss., 13, 9801-9847, doi:10.5194/acpd-13-9801-2013, 2013.

Lewis, E. R. and Schwartz, S. E.: Sea Salt Aerosol Production: Mechanisms, Methods, Measurements and Models - a Critical Review, American Geophysical Union, Geophysical Monograph Series, 152, John Wiley \& Sons, Inc., USA, doi:10.1029/GM152, 2004.

Li, X., Leck, C., Sun, L., Hede, T., Tu, Y., and Agren, H.: Cross-linked polysaccharide assemblies in marine gels: an atomistic simulation, J. Phys. Chem. Lett., 4, 2637-2642, doi:10.1021/jz401276r, 2013.

Lindsay, R. W., Zhang, J., Schweiger, A., Steele, M., and Stern, H.: Arctic Sea ice retreat in 2007 follows thinning trend, J. Climate, 22, 165-176, doi:10.1175/2008JCLI2521.1, 2009.

Mattsson, R., Paatero, J., and Hatakka, J.: Automatic alpha/beta analyser for air filter samples - absolute determination of radon progeny by pseudo-coincidence techniques, Radiat. Prot. Dosim., 63, 133-139, 1996.

Mauney, T., Adams, F., and Sine, M. R.: Laser microprobe mass spectrometry of environmental soot particles, Sci. Total Environ., 36, 215-224, doi:10.1016/0048-9697(84)90269-9, 1984.
Mauritsen, T., Sedlar, J., Tjernström, M., Leck, C., Martin, M., Shupe, M., Sjogren, S., Sierau, B., Persson, P. O. G., Brooks, I. M., and Swietlicki, E.: An Arctic CCN-limited cloud-aerosol regime, Atmos. Chem. Phys., 11, 165-173, doi:10.5194/acp-11-165-2011, 2011.

McLafferty, F. W. and Turecek, F.: Interpretation of Mass Spectra, 4 edn., University Science Books, Sausalito, CA, USA, 1993.

Moffet, R. C., de Foy, B., Molina, L. T., Molina, M. J., and Prather, K. A.: Measurement of ambient aerosols in northern Mexico City by single particle mass spectrometry, Atmos. Chem. Phys., 8, 4499-4516, doi:10.5194/acp-8-4499-2008, 2008.

Neubauer, K., Johnston, M. V., and Wexler, A.: On-line analysis of aqueous aerosols by laser desorption ionization, Int. J. Mass Spectrom., 163, 29-37, doi:10.1016/S0168-1176(96)04534-X, 1997.

Neubauer, K., Johnston, M., and Wexler, A.: Humidity effects on the mass spectra of single aerosol particles, Atmos. Environ., 32, 2521-2529, doi:10.1016/S1352-2310(98)00005-3, 1998.

Nilsson, E. D. and Leck, C.: A pseudo-Lagrangian study of the sulfur budget in the remote Arctic marine boundary layer, Tellus B, 54, 213-230, doi:10.1034/j.1600-0889.2002.01247.x, 2002.

Norris, S. J., Brooks, I. M., de Leeuw, G., Sirevaag, A., Leck, C., Brooks, B. J., Birch, C. E., and Tjernström, M.: Measurements of bubble size spectra within leads in the Arctic summer pack ice, Ocean Sci., 7, 129-139, doi:10.5194/os-7-129-2011, 2011.

Orellana, M. V., Matrai, P. A., Leck, C., Rauschenberg, C. D., Lee, A. M., and Coz, E.: Marine microgels as a source of cloud condensation nuclei in the high Arctic, P. Natl. Acad. Sci. USA, 108, 13612-13617, doi:10.1073/pnas.1102457108, 2011.

Paatero, J., Vaattovaara, P., Vestenius, M., Meinander, O., Makkonen, U., Kivi, R., Hyvärinen, A., Asmi, E., Tjernström, M., and Leck, C.: Finnish contribution to the Arctic Summer Cloud Study (ASCOS) expedition, Arctic Ocean 2008, Geophysica, 45, 119146, Polardok by Swedish Polar Research Secretariat, Geophysical Society of Finland, Helsinki, 2009.

Pagels, J., Strand, M., Rissler, J., Szpila, A., Gudmundsson, A., Bohgard, M., Lillieblad, L., Sanati, M., and Swietlicki, E.: Characteristics of aerosol particles formed during grate combustion of moist forest residue, J. Aerosol Sci., 34, 1043-1059, doi:10.1016/S0021-8502(03)00077-6, 2003.

Pagels, J., Dutcher, D. D., Stolzenburg, M. R., McMurry, P. H., Gälli, M. E., and Gross, D. S.: Fine-particle emissions from solid biofuel combustion studied with single-particle mass spectrometry: identification of markers for organics, soot, and ash components, J. Geophys. Res., 118, 859-870, doi:10.1029/2012JD018389, 2013.

Pakkanen, T. A., Kerminen, V., Hillamo, R. E., Màkinen, M., Màkelà, T., and Virkkula, A.: Distribution of nitrate over seasalt and soil derived particles - implications from a field study, J. Atmos. Chem., 24, 189-205, doi:10.1007/BF00162410, 1996.

Pastor, S., Allen, J., Hughes, L., Bhave, P., Cass, G., and Prather, K.: Ambient single particle analysis in Riverside, California by aerosol time-of-flight mass spectrometry during the SCOS97NARSTO, Atmos. Environ., 37, 239-258, doi:10.1016/S13522310(03)00393-5, 2003.

Prather, K. A., Bertram, T. H., Grassian, V. H., Deane, G. B., Stokes, M. D., DeMott, P. J., Aluwihare, L. I., Palenik, B. P., Azam, F., Seinfeld, J. H., Moffet, R. C., Molina, M. J., Cappa, C. D., Geiger, F. M., Roberts, G. C., Russell, L. M., 
Ault, A. P., Baltrusaitis, J., Collins, D. B., Corrigan, C. E., Cuadra-Rodriguez, L. A., Ebben, C. J., Forestieri, S. D., Guasco, T. L., Hersey, S. P., Kim, M. J., Lambert, W. F., Modini, R. L., Mui, W., Pedler, B. E., Ruppel, M. J., Ryder, O. S., Schoepp, N. G., Sullivan, R. C., and Zhao, D.: Bringing the ocean into the laboratory to probe the chemical complexity of sea spray aerosol, P. Natl. Acad. Sci. USA, 110, 7550-7555, doi:10.1073/pnas.1300262110, 2013.

Pratt, K. A. and Prather, K. A.: Aircraft measurements of vertical profiles of aerosol mixing states, J. Geophys. Res., 115, D11305, doi:10.1029/2009JD013150, 2010.

Pratt, K. A., DeMott, P. J., French, J. R., Wang, Z., Westphal, D. L., Heymsfield, A. J., Twohy, C. H., Prenni, A. J., and Prather, K. A.: In situ detection of biological particles in cloud ice-crystals, Nat. Geosci., 2, 398-401, 2009.

Prenni, A. J., DeMott, P. J., Kreidenweis, S. M., Harrington, J. Y., Avramov, A., Verlinde, J., Tjernström, M., Long, C. N., and Olsson, P. Q.: Can ice-nucleating aerosols affect arctic seasonal climate?, B. Am. Meteorol. Soc., 88, 541-550, doi:10.1175/BAMS-88-4-541, 2007.

Qin, X. and Prather, K. A.: Impact of biomass emissions on particle chemistry during the California Regional Particulate Air Quality Study, Int. J. Mass Spectrom., 258, 142-150, doi:10.1016/j.ijms.2006.09.004, 2006.

Qin, X., Pratt, K. A., Shields, L. G., Toner, S. M., and Prather, K. A.: Seasonal comparisons of single-particle chemical mixing state in Riverside, CA, Atmos. Environ., 59, 587-596, doi:10.1016/j.atmosenv.2012.05.032, 2012.

Quinn, P. K., Shaw, G., Andrews, E., Dutton, E., Ruoho-Airola, T., and Gong, S.: Arctic haze: current trends and knowledge gaps, Tellus B, 59, 99-114, doi:10.1111/j.1600-0889.2006.00238.x, 2007.

Reilly, P. T. A., Lazar, A. C., Gieray, R. A., Whitten, W. B., and Ramsey, J. M.: The elucidation of charge-transfer-induced matrix effects in environmental aerosols via real-time aerosol mass spectral analysis of individual airborne particles, Aerosol Sci. Tech., 33, 135-152, doi:10.1080/027868200410895, 2000.

Sedlar, J., Tjernström, M., Mauritsen, T., Shupe, M., Brooks, I., Persson, P., Birch, C., Leck, C., Sirevaag, A., and Nicolaus, M.: A transitioning Arctic surface energy budget: the impacts of solar zenith angle, surface albedo and cloud radiative forcing, Clim. Dynam., 37, 1643-1660, doi:10.1007/s00382-010-0937-5, 2011.

Shields, L. G.: Single Particle Characterization, Source Apportionment, and Aging Effects of Ambient Aerosols in Southern California, Ph.D. thesis, University of California, San Diego, 2008.

Shupe, M. D., Uttal, T., and Matrosov, S. Y.: Arctic cloud microphysics retrievals from surface-based remote sensors at SHEBA, J. Appl. Meteorol., 44, 1544-1562, 2005.

Shupe, M. D., Walden, V. P., Eloranta, E., Uttal, T., Campbell, J. R., Starkweather, S. M., and Shiobara, M.: Clouds at Arctic atmospheric observatories - Part I: Occurrence and macrophysical properties, J. Appl. Meteorol. Clim., 50, 626-644, 2011.

Shupe, M. D., Persson, P. O. G., Brooks, I. M., Tjernström, M., Sedlar, J., Mauritsen, T., Sjogren, S., and Leck, C.: Cloud and boundary layer interactions over the Arctic sea ice in late summer, Atmos. Chem. Phys., 13, 9379-9399, doi:10.5194/acp-139379-2013, 2013.

Silva, P., Liu, D.-Y., Noble, C., and Prather, K.: Size and chemical characterization of individual particles resulting from biomass burning of local Southern California species, Environ. Sci. Technol., 33, 3068-3076, 1999.

Silva, P. J. and Prather, K. A.: Interpretation of mass spectra from organic compounds in aerosol time-of-flight mass spectrometry, Anal. Chem., 72, 3553-3562, doi:10.1021/ac9910132, 2000.

Song, C. H. and Carmichael, G. R.: The aging process of naturally emitted aerosol (sea-salt and mineral aerosol) during long range transport, Atmos. Environ., 33, 2203-2218, doi:10.1016/S13522310(98)00301-X, 1999.

Spencer, M. T., Holecek, J. C., Corrigan, C. E., Ramanathan, V., and Prather, K. A.: Size-resolved chemical composition of aerosol particles during a monsoonal transition period over the Indian Ocean, J. Geophys. Res., 113, D16305, doi:10.1029/2007JD008657, 2008.

Stohl, A.: Characteristics of atmospheric transport into the Arctic troposphere, J. Geophys. Res., 111, D11306, doi:10.1029/2005JD006888, 2006.

Stohl, A., Hittenberger, M., and Wotawa, G.: Validation of the lagrangian particle dispersion model FLEXPART against largescale tracer experiment data, Atmos. Environ., 32, 4245-4264, doi:10.1016/S1352-2310(98)00184-8, 1998.

Tjernström, M.: The summer arctic boundary layer during the Arctic Ocean Experiment 2001 (AOE-2001), Bound.-Lay. Meteorol., 117, 5-36, 2005.

Tjernström, M., Leck, C., Persson, P. O. G., Jensen, M. L., Oncley, S. P., and Targino, A.: The summertime Arctic atmosphere: meteorological measurements during the Arctic Ocean Experiment 2001, B. Am. Meteorol. Soc., 85, 1305-1321, doi:10.1175/BAMS-85-9-1305, 2004.

Tjernström, M., Zagar, M., Svensson, G., Cassano, J. C., Pfeifer, S., Rinke, A., Wyser, K., Dethloff, K., Jones, C., Semmler, T., and Shaw, M.: Modelling the Arctic boundary layer: an evaluation of six ARCMIP regional-scale models using data from the SHEBA project, Bound.-Lay. Meteorol., 117, 337-381, 2005.

Tjernström, M., Birch, C. E., Brooks, I. M., Shupe, M. D., Persson, P. O. G., Sedlar, J., Mauritsen, T., Leck, C., Paatero, J., Szczodrak, M., and Wheeler, C. R.: Meteorological conditions in the central Arctic summer during the Arctic Summer Cloud Ocean Study (ASCOS), Atmos. Chem. Phys., 12, 6863-6889, doi:10.5194/acp-12-6863-2012, 2012.

Tjernström, M., Leck, C., Birch, C. E., Brooks, B. J., Brooks, I. M., Bäcklin, L., Chang, R. Y.-W., Granath, E., Graus, M., Hansel, A., Heintzenberg, J., Held, A., Hind, A., de la Rosa, S., Johnston, P., Knulst, J., de Leeuw, G., Di Liberto, L., Martin, M., Matrai, P. A., Mauritsen, T., Müller, M., Norris, S. J., Orellana, M. V., Orsini, D. A., Paatero, J., Persson, P. O. G., Gao, Q., Rauschenberg, C., Ristovski, Z., Sedlar, J., Shupe, M. D., Sierau, B., Sirevaag, A., Sjogren, S., Stetzer, O., Swietlicki, E., Szczodrak, M., Vaattovaara, P., Wahlberg, N., Westberg, M., and Wheeler, C. R.: The Arctic Summer Cloud-Ocean Study (ASCOS): overview and experimental design, Atmos. Chem. Phys. Discuss., 13, 13541-13652, doi:10.5194/acpd-13-13541-2013, 2013.

Ulbrich, I. M., Canagaratna, M. R., Zhang, Q., Worsnop, D. R., and Jimenez, J. L.: Interpretation of organic components from Positive Matrix Factorization of aerosol mass spectrometric data, Atmos. Chem. Phys., 9, 2891-2918, doi:10.5194/acp-9-2891-2009, 2009. 
Verdugo, P.: Marine microgels, Ann. Rev. Marine Sci., 4, 375-400, doi:10.1146/annurev-marine-120709-142759, 2012.

Wenzel, R. J., Liu, D., Edgerton, E. S., and Prather, K. A.: Aerosol time-of-flight mass spectrometry during the Atlanta Supersite Experiment: 2. Scaling procedures, J. Geophys. Res., 108, 8427, doi:10.1029/2001JD001563, 2003.

Wiedensohler, A., Covert, D., Swietlicki, E., Aalto, P., Heintzenberg, J., and Leck, C.: Occurrence of an ultrafine particle mode less than $20 \mathrm{~nm}$ in diameter in the marine boundary layer during Arctic summer and autumn, Tellus B, 48, 213-222, doi:10.1034/j.1600-0889.1996.t01-1-00006.x, 1996.

Zelenyuk, A. and Imre, D.: Single particle laser ablation time-offlight mass spectrometer: an introduction to SPLAT, Aerosol Sci. Tech., 39, 554-568, doi:10.1080/027868291009242, 2005.
Zhang, Q., Jimenez, J. L., Canagaratna, M. R., Allan, J. D., Coe, H., Ulbrich, I., Alfarra, M. R., Takami, A., Middlebrook, A. M., Sun, Y. L., Dzepina, K., Dunlea, E., Docherty, K., DeCarlo, P. F., Salcedo, D., Onasch, T., Jayne, J. T., Miyoshi, T., Shimono, A., Hatakeyama, S., Takegawa, N., Kondo, Y., Schneider, J., Drewnick, F., Borrmann, S., Weimer, S., Demerjian, K., Williams, P., Bower, K., Bahreini, R., Cottrell, L., Griffin, R. J., Rautiainen, J., Sun, J. Y., Zhang, Y. M., and Worsnop, D. R.: Ubiquity and dominance of oxygenated species in organic aerosols in anthropogenically-influenced Northern Hemisphere midlatitudes, Geophys. Res. Lett., 34, L13801, doi:10.1029/2007GL029979, 2007. 